\title{
Factors Regulating microRNA Expression and Function in Multiple Myeloma
}

\author{
Irena Misiewicz-Krzeminska ${ }^{1,2,3}{ }^{(D)}$, Patryk Krzeminski ${ }^{1,2}$, Luis A. Corchete ${ }^{1,2}{ }^{\mathbb{C}}$, \\ Dalia Quwaider ${ }^{1,2}$, Elizabeta A. Rojas ${ }^{1,2,4}$, Ana Belén Herrero ${ }^{1,2}$ and Norma C. Gutiérrez ${ }^{1,2,5,6, *}$ \\ 1 The Institute for Biomedical Research (IBSAL), 37007 Salamanca, Spain; irenamk@usal.es (I.M.-K.); \\ patrykk@usal.es (P.K.); lacorsan@usal.es (L.A.C.); dalia@usal.es (D.Q.); elirr@usal.es (E.A.R.); \\ anah@usal.es (A.B.H.) \\ 2 Cancer Research Center-IBMCC (USAL-CSIC), 37007 Salamanca, Spain \\ 3 National Medicines Institute, 00725 Warsaw, Poland \\ 4 Faculty of Medicine, University of Salamanca, 37007 Salamanca, Spain \\ 5 Hematology Department, University Hospital of Salamanca, 37007 Salamanca, Spain \\ 6 Centro de Investigación Biomédica en Red de Cáncer (CIBERONC) number CB16/12/00233, \\ 37007 Salamanca, Spain \\ * Correspondence: normagu@usal.es; Tel.: +34-923-291-384; Fax: +34-923-294-624
}

Received: 30 October 2018; Accepted: 15 January 2019; Published: 16 January 2019

check for updates

\begin{abstract}
Intensive research has been undertaken during the last decade to identify the implication of microRNAs (miRNAs) in the pathogenesis of multiple myeloma (MM). The expression profiling of miRNAs in MM has provided relevant information, demonstrating different patterns of miRNA expression depending on the genetic abnormalities of $\mathrm{MM}$ and a key role of some miRNAs regulating critical genes associated with MM pathogenesis. However, the underlying causes of abnormal expression of miRNAs in myeloma cells remain mainly elusive. The final expression of the mature miRNAs is subject to multiple regulation mechanisms, such as copy number alterations, CpG methylation or transcription factors, together with impairment in miRNA biogenesis and differences in availability of the mRNA target sequence. In this review, we summarize the available knowledge about the factors involved in the regulation of miRNA expression and functionality in MM.
\end{abstract}

Keywords: miRNA; myeloma multiple; miRNA regulation; methylation

\section{Introduction}

Multiple myeloma (MM) is a neoplasm characterized by the accumulation of clonal plasma cells (PC) in bone marrow, which is generally associated with the production of a monoclonal immunoglobulin and lytic bone lesions. MM accounts for $1 \%$ of all cancers and approximately $10 \%$ of all hematologic malignances. Although the incorporation of new drugs with different mechanisms of action has dramatically changed the perspective of treatment with an improvement in the median overall survival rate, it remains an incurable disease [1].

Similar to other cancer types, MM is a cytogenetically heterogeneous disease. Initial studies of conventional cytogenetics and fluorescent in situ hybridization (FISH), and more advanced studies based on microarrays and new generation sequencing (NGS), have revealed the existence of different types of genetic alterations that can be categorized into translocations, copy number abnormalities (CNAs) and point mutations [2-4]. The majority of chromosomal translocations affect IGH locus at $14 \mathrm{q} 32$, which occur in approximately 50\% of MMs. Five chromosomal partners account for most of the IGH translocations in MM, 11q13, 4p16, 16q23, 6p21, and 20q11. These translocations lead to the overexpression of cyclin D1, FGFR3/MMSET, c-MAF, cyclin D3, and MAF-B, respectively. The presence 
of $t(4 ; 14), t(14 ; 16)$ or $t(14 ; 20)$ translocations have being associated with poor prognosis. Moreover, a significant proportion of translocations in MM involves MYC oncogene (about 15\%). CNAs are present in almost all MM patients; among them, the most frequent are gains of the entire chromosomes $5,7,9,11,15,19,21$ and gains of $1 q$ arm, and loss of $1 p, 13 q$ and $17 p$. Several studies have shown that $1 q$ gains and $1 p$ deletions are associated with short survival. Deletion of $17 p$, which contains the TP53 locus, is present in 10\%, and remains a strong prognostic factor, which has been associated with a negative effect on survival in different treatment contexts. Whole-genome and whole-exome-based sequencing strategies have shown that there are few recurrently mutated genes in myeloma. Mutations affecting the MAPK pathway, including those in KRAS, NRAS and $B R A F$, are detected in approximately $40 \%$ of patients. Other mutations, such as those involving FAM46C, TP53, DIS3, PRDM1, EGR1, TRAF3, CCND1, ATM, IRF4, and FGFR3, were present in less than $10 \%$ of cases [5].

However, as demonstrated in other tumors, most of the changes in the gene expression in $\mathrm{MM}$ are apparently not preceded by alterations in DNA in the form of mutations, chromosomal anomalies or even epigenetic modifications (DNA methylation). The fact that steps of the embryological development depend on changes in gene expression and mainly occur without alterations in DNA supports the role of post-transcriptional regulation as a key mechanism for modifying gene expression levels in the absence of DNA abnormalities. Post-transcriptional gene regulation by microRNAs (miRNAs) has been the most widely investigated, since they can control the activity of more than $30 \%$ of all protein-coding genes. MicroRNAs are small regulatory RNAs, ranging from 19 to $25 \mathrm{nt}$, which are encoded from the genomic DNA. Most human miRNA genes are located between protein-coding genes (intergenic miRNAs), while about one-third of them have been found inside protein-coding genes, called host genes [6]. Moreover, there are miRNA genes, both inter- and intra-genic, that are clustered. Generally, there are between two and three miRNA genes in a cluster, but larger clusters have also been identified, like the miR-17-92 cluster composed of six members [7]. The expression of miRNAs is regulated by multiple factors and molecular mechanisms, from those affecting the DNA copy number, methylation of CpGs, transcription factors, and miRNA biogenesis, to those modifying the miRNA binding site's availability in the mRNA sequence.

In humans, as well as in other mammalians, almost 2000 different miRNAs have been identified, according to miRBase [8]. Although different functions have been described for miRNAs, the most relevant is the downregulation of gene expression at the post-transcriptional level by targeting specific messenger RNAs (mRNAs), either for degradation when fully paired to the seed region binding site at the $3^{\prime}$ untranslated region ( $\left.3^{\prime} \mathrm{UTR}\right)$ of the mRNA target, or for inhibition of translation through partial base-pairing to complementary sites. Conversely, miRNAs might upregulate translation by other diverse mechanisms (reviewed in [9]).

MiRNAs are involved in critical biological processes, including cellular growth and differentiation, and can contribute to cancer pathogenesis (reviewed in [10-14]). In this regard, miRNAs have also been shown to be deregulated in MM. miRNA expression is deregulated in MM cells when compared to normal plasma cells [15-17], and several studies have demonstrated their key role in MM pathogenesis [18-24]. Below, a comprehensive review of the main mechanisms regulating miRNA expression and function, with focus on data available in MM, will be provided.

\section{Copy Number Abnormalities Affect Expression of miRNAs}

Mutations in the DNA sequences encoding miRNA is a rather rare event [25,26]. Genes, including those encoding miRNAs, can also be deregulated by copy number alterations of their loci (CNA). In primary MM samples, integrative analyses have identified a gene dosage effect induced by copy number changes on the expression of many mature miRNAs (Figure 1). One of the most frequent CNAs in MM is 1q gain, observed in more than $50 \%$ of patients [27]. The overexpression of miRNAs located at 1q, such as miR-1231, miR-205, miR-215 and miR-488, was correlated with the gain of this chromosomal region [17]. miR-215 directly targets MDM2, a negative regulator of p53 protein, and IGF-1 and IGF-1R, which control mobility and invasive properties of MM cells [28]. 
A cluster of $m i R-520 a-5 p, m i R-518 d-5 p, m i R-498$ and $m i R-520 g$, located at $19 q$, has been shown to be upregulated in those MM patients with 19q gains [17]. These miRNAs target p21, involved in cell cycle regulation [29], and FOXO3, a transcription factor implicated in cell growth, proliferation, and development of cancer [30]. However, their contribution to the pathogenesis of MM is unknown. Regarding chromosomal losses, monosomy and deletions of chromosome 13 are detected in up to $50 \%$ of MM cases [2,3]. Some of the miRNAs located at this region are downregulated in primary MM samples with del(13q), like miR-15a/16 cluster and members of the miR-17-92 cluster (miR-17, $m i R 19 a$ and $m i R-20 a)[15,31]$. miR-15a and miR-16 downregulation contributes to MM pathogenesis by promoting cells growth and neoangiogenesis in bone marrow [31]. A high level of the miR-17-92 cluster is, on the other hand, associated with poor prognosis in patients with MM, and it has been speculated that other factors may counteract the chromosome 13 deletion effect leading to the overexpression of these miRNAs in MM, as discussed below [32]. Furthermore, miR-22, encoded at the 17p locus, was significantly less expressed in those patients with the $17 \mathrm{p}$ deletion. [33]. Recently, miR-22 has been identified as a tumor-suppressing miRNA and its expression is decreased in a variety of human neoplasms [34-37]. Moreover, the downregulation of 14 miRNAs in the presence of loss of heterozygosity $(\mathrm{LOH})$ has been detected, such as let-7b at $22 \mathrm{q}$, miR-662 at $16 \mathrm{p}$ or miR-140-3p at 16q [17]. A probable consequence in MM can arise from the fact that let-7 miRNAs (a family of 9 mature let-7, encoded by 12 different genomic loci (reviewed in [38])) function as a tumor suppressor through regulation of key oncogenes, including MYC and RAS [39,40]. Low expression of let-7 family members is associated with poor prognosis in several cancer types [41,42]. In human myeloma cell lines (HMCLs), 61\% of miRNA gene loci were affected by CNAs, showing a predominance of gains versus losses [33].

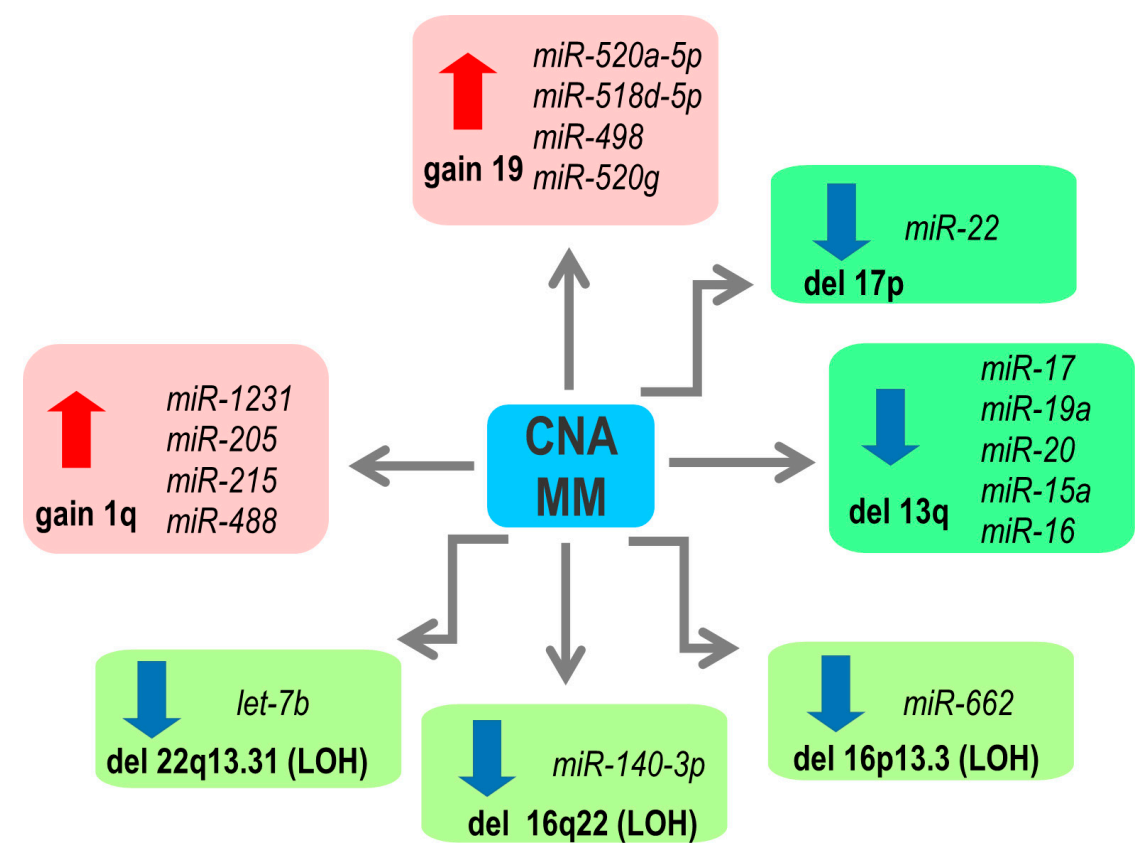

Figure 1. Copy number abnormalities (CNA) of genes encoding microRNAs (miRNAs) with impact on the miRNA expression in multiple myeloma (MM). LOH: loss of heterozygosity.

\section{3. microRNA Expression and Epigenetics}

Epigenetic modifications have a strong impact on gene expression regulation. Genes with methylated $\mathrm{CpG}$ in the promoters are typically repressed, while genes with unmethylated promoters can be expressed or not depending on other mechanism of expression regulation (reviewed in [43]). In many tumors, changes of DNA methylation have been found to be correlated with disease stage and patient survival (reviewed in [44]). In MM, the global DNA methylation level was observed 
to decrease from monoclonal gammopathy of undetermined significance (MGUS) to MM, although without further changes between newly diagnosed and relapsed cases $[45,46]$. Moreover, methylation of DNA encoding particular miRNAs has also been correlated with cancer progression. Increased methylation of the promoter regions of $m i R-34 a$ [47], miR-152, miR-10b-5p [48] and miR-203 was observed in MM cells compared to normal plasma cells [49]. In this regard, hypermethylation of $m i R-34 b / c$ and $m i R-129-2$ has been detected during the transformation from MGUS to MM, as well as in MM relapse/progression [50,51]. Moreover, $m i R-375$ and $m i R-342-3 p$ hypermethylation was also found in relapsed/progressed MM [52,53].

Many studies have been focused on analyzing the effect of the function restoration of those miRNAs downregulated by methylation. Such experiments, either using hypomethylating agents such as decitabine, or transfection with the particular miRNA, have demonstrated that forced expression of $m i R-10 b-5 p, m i R-34 b, m i R-34 c-3 p, m i R-29 b, m i R-152, m i R-194 b$ and $m i R-203$ resulted in decreased proliferation and induction of apoptosis [28,48-50].

Conversely, some miRNAs can directly affect epigenetic machinery by modulating the expression of enzymes, such as DNA methyltransferases (DNMT1, DNMT3a and DNMT3b) or histone methyltransferases. These miRNAs are often considered as a family of epigenetic miRNAs, "epi-miRNAs" [54]. In MM, DNMT1 has been shown to be targeted by miR-152, whereas miR-126 and miR-140-3p decrease DNMT1 expression in other diseases [55,56]. Hypomethylation treatment or miR-152 transfection of MM cells resulted in the decreased expression of DNMT1, E2F3 [48]. The role of miR-126 and miR-140-3p has been investigated in the interplay between myeloma cells and microenvironment. Co-culturing WL2 MM cells with bone marrow stromal cells (BMSC) revealed increased expression of miR-126 and miR-140-3p, which led to repression of DNMT1 and upregulation of RANKL [57]. The effect of the microenvironment on the enzymes responsible for DNA methylation is further supported by the experiments demonstrating increased expression of two DNA methyltransferases, DNMT3A and DNMT3B, after co-culture of MM cells with BMSC [58]. Moreover, expression of DNMT3A and DNMT3B is downregulated by $m i R-29 b$ [59]. Overexpression of $m i R-29 b$ reduced general DNA methylation two-fold. Interestingly, expression of $m i R-29 b$ was increased by downregulation of histone methyltransferase EZH2 [60]. miR-29b also targets the anti-apoptotic MCL-1 protein [61], CDK6, PSME4 [62] and HDAC4 [21], which further supports links among epigenetics modification, drug resistance and apoptosis. A summary of epigenetically regulated miRNA is presented in Table 1.

Table 1. Brief summary of the DNA methylation status and function of miRNA in MM.

\begin{tabular}{|c|c|c|c|}
\hline miRNA & $\begin{array}{l}\text { Methylation Status in NPC, } \\
\text { MM and HMCLs }\end{array}$ & Function in $\mathrm{MM}$ & Ref. \\
\hline 9-3 and 9-1 & $\begin{array}{l}\text { Unmethylated in MM, methylated in } \\
\text { HMCLs }\end{array}$ & $\begin{array}{l}\text { CD44 overexpression, (glycoprotein that } \\
\text { has been associated with lenalidomide and } \\
\text { dexamethasone resistance in myeloma) }\end{array}$ & {$[63,64]$} \\
\hline $10 b-5 p$ & $\begin{array}{l}\text { Methylated in MM } \\
\text { Upregulated after 5-aza-CdR in HMCLs }\end{array}$ & Not tested & [48] \\
\hline 28 & $\begin{array}{l}\text { Unmethylated in healthy controls and at } \\
\text { MM relapse, methylated in some HMCLs }\end{array}$ & $\begin{array}{l}\text { Inverse correlation between CCND1 } \\
\text { expression and } L P P / m i R-28 \text { methylation }\end{array}$ & [65] \\
\hline $34 a$ & $\begin{array}{l}\text { Methylated in primary MM, no difference } \\
\text { between diagnosis and relapse, highly } \\
\text { methylated in HMCLs }\end{array}$ & $\begin{array}{l}\text { Inhibition of MM growth and reduction of } \\
\text { bone lesions by targeting TGIF2 }\end{array}$ & {$[47,66]$} \\
\hline $34 b / c$ & $\begin{array}{l}\text { Methylated in MM, increased methylation } \\
\text { in relapsed MM, highly methylated in } \\
\text { HMCLs }\end{array}$ & $\begin{array}{l}\text { Inhibition of cellular proliferation and } \\
\text { induction of apoptosis in MM cells }\end{array}$ & [50] \\
\hline $124-1$ & $\begin{array}{l}\text { Methylated in primary MM, highly } \\
\text { methylated in HMCLs }\end{array}$ & Repression of CDK6 & [67] \\
\hline 129 & $\begin{array}{l}\text { Methylation increases from MGUS to MM } \\
\text { at diagnosis and at relapse/progression }\end{array}$ & Downregulation of SOX4 & [51] \\
\hline 152 & $\begin{array}{l}\text { Highly methylated in MM and in HMCLs } \\
\text { Upregulated after 5-aza-CdR in HMCLs } \\
\text { Targets DNMT1 }\end{array}$ & $\begin{array}{l}\text { Decrease of DNMT1 and E2F2 Induction of } \\
\text { apoptosis in MM cells }\end{array}$ & [48] \\
\hline
\end{tabular}


Table 1. Cont.

\begin{tabular}{|c|c|c|c|}
\hline miRNA & $\begin{array}{l}\text { Methylation Status in NPC, } \\
\text { MM and HMCLs }\end{array}$ & Function in $\mathrm{MM}$ & Ref. \\
\hline 155 & $\begin{array}{l}\text { Highly methylated in HMCLs } \\
\text { Expression induced by LPS only when } \\
\text { unmethylated in HMCLs }\end{array}$ & $\begin{array}{l}\text { High expression of } m i R-155 \text { was associated } \\
\text { with improved overall survival (OS) } \\
\text { in MM. }\end{array}$ & [68] \\
\hline 192,194 and 215 & Methylated in MM cell lines & $\begin{array}{l}\text { High expression of } m i R-194 \text { was associated } \\
\text { with improved OS in MM. } \\
\text { Overexpression associated with inhibition } \\
\text { of cellular proliferation and migration }\end{array}$ & [28] \\
\hline $\begin{array}{l}198,135 a^{*}, 200 c \\
125 a-3 p, 188-5 p \\
483-5 p, 663,630\end{array}$ & $\begin{array}{l}\text { Methylated in MM } \\
\text { Upregulated after 5-aza-CdR in HMCLs }\end{array}$ & Not tested & [69] \\
\hline 203 & Methylated in HMCLs & $\begin{array}{l}\text { Downregulation of CREB1 protein and } \\
\text { inhibition of proliferation of myeloma cells }\end{array}$ & [49] \\
\hline $342-3 p$ & $\begin{array}{l}\text { Methylated in MGUS and increased } \\
\text { methylation in relapsed MM } \\
\text { Upregulated after 5-aza-CdR in HMCLs }\end{array}$ & Not tested & [52] \\
\hline 375 & Methylated in MM and HMCLs & Downregulation of PDPK1 and IGF1R & [53] \\
\hline
\end{tabular}

Abbreviations: normal plasma cells (NPC), multiple myeloma (MM), Monoclonal gammopathy of undetermined significance (MGUS) and human myeloma cell lines (HMCLs).

\section{Transcriptional Regulation of miRNA Expression}

Intragenic miRNAs, located within introns or exons of protein-coding genes, are co-transcribed by Pol II and their expression is generally regulated by the same mechanisms as those of the host genes $[6,70]$. Little evidence exists about the relationship between expression of miRNAs and their host genes in primary MM samples, but so far no significant correlation between the intronic miRNAs and their host transcript expression has been detected [15]. Moreover, analysis of microarray-based datasets in various cell types, including MM, revealed that the large majority of intragenic miRNAs are not co-expressed with their host genes, and in MM only $11 \%$ of them were significantly correlated [71]. In HMCLs however, several associations have been described and are summarized in Table 2.

Table 2. miRNA co-regulated with their host genes and the mechanism described in MM.

\begin{tabular}{|c|c|c|c|c|}
\hline Gene Locus & miRNA & Host Gene & Regulation Mechanism & Ref. \\
\hline $7 q 32.2$ & $m i R-335$ & MEST & Not by CNA & {$[33,72]$} \\
\hline $14 \mathrm{q} 32.2$ & $\operatorname{miR}-342-3 p$ & $E V L$ & $\begin{array}{l}\text { By promoter DNA methylation of its host gene, } \\
\text { not by CNA }\end{array}$ & {$[33,72]$} \\
\hline $2 q 32.1-q 32.2$ & $m i R-561$ & GULP1 & Not by CNA & {$[33,72]$} \\
\hline $17 q 21.32$ & miR-152 & COPZ2 & Unknown & [33] \\
\hline $3 q 27.3-q 28$ & $m i R-28-5 p$ & $L P P$ & By promoter DNA methylation of the host gene & [65] \\
\hline $17 q 23.1$ & $m i R-21$ & TMEM49 & $\begin{array}{l}\text { By an upstream enhancer, overlapping with } \\
\text { intronic region of the host gene }\end{array}$ & [73] \\
\hline $21 q 21.3$ & $m i R-155$ & $B I C$ & By promoter DNA methylation of the host gene & [68] \\
\hline
\end{tabular}

The intergenic miRNAs are transcribed from their own promoter by Pol II or Pol III, and a small group of miRNAs can be transcribed without any exogenous promoter $[6,70,74]$. Several transcription factors (TFs) have been described to regulate the intergenic miRNAs expression in MM (Figure 2).

A number of studies indicate that the bone marrow microenvironment (BMM) induces growth-promoting effects by modulating the expression of miRNAs [75,76]. The first published work regarding the regulation of miRNA expression in MM showed that interleukin 6 (IL6), the cytokine produced by bone marrow mesenchymal stem cells, induced changes in miRNA expression enhancing survival and drug resistance of myeloma cells. One of the miRNAs induced by IL6 is miR-21, whose stimulation is mediated by an upstream enhancer, the regulatory site that contains STAT3 binding sites. STAT3-mediated induction of miR-21 has a pro-survival effect on MM cells, since ectopic increase of $m i R-21$ in IL6-dependent MM cell lines abolished the dependency on this cytokine [73]. STAT3 has been previously shown to induce the expression of anti-apoptotic genes, like survivin, $\mathrm{Bcl}-2$ or MCL1 [77,78]. Moreover, downregulation of IL6 by treatment with berberine (a natural alkaloid 
derived from a traditional Chinese herbal medicine) decreased miR-21 transcription through STAT3 down-regulation, which further validate the prosurvival impact of miR-21 in MM [73]. Additional evidence of miR-21 regulation by STAT3 was provided using ibrutinib (BTK inhibitor), which inhibits $m i R-21$ transcription by disrupting NF-kB and STAT3 binding to the miR-21 promoter [79]. Moreover, BMM is highly hypoxic, which leads in MM cells to an AKT-mediated decrease of miR-199-5p expression, and consequently to increased expression of HIF-1 $\alpha$ [80], a transcription factor involved in hypoxia response [81].

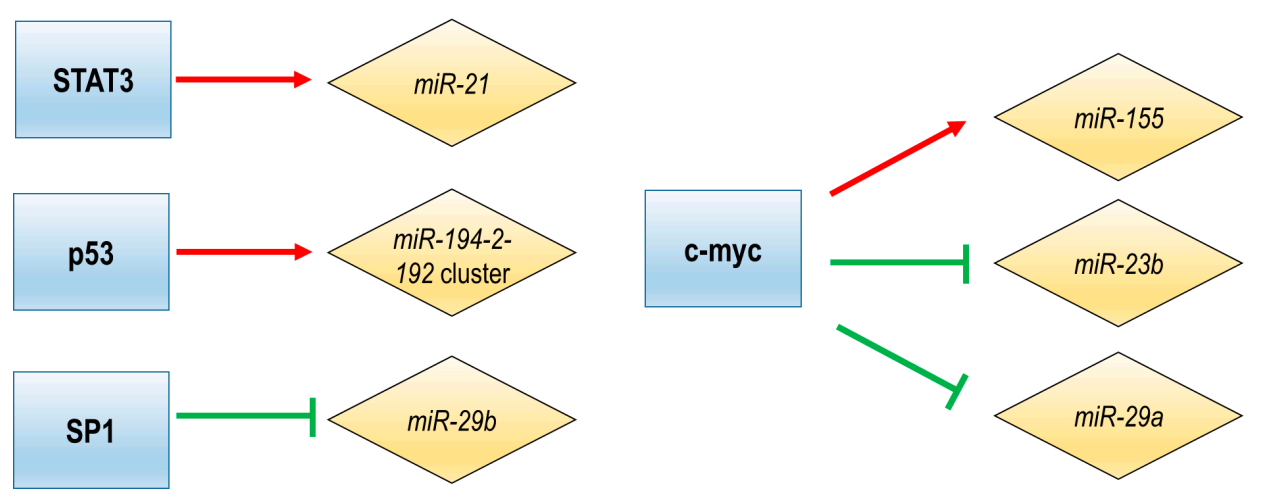

Figure 2. Regulation of miRNA expression by transcription factors (TFs) in MM.

C-Myc is a transcription factor with recognized oncogenic functions. In MM, c-Myc deregulation is one of the key events associated with disease progression (reviewed in [82]). In order to regulate the transcription of the genes, c-Myc binds to DNA at multiple regulatory sites, one being the so-called E-Box. This evolutionary conserved DNA site was detected in the host gene of miR-155 [68], one of the miRNAs essential for the B-lineage lymphocyte [83,84]. In fact, it has been demonstrated that c-Myc, Mad1 and Max regulate the expression of miR-155 in MM by binding to this E-Box site [68]. In addition to miR-155, c-Myc activation results in widespread reprogramming of the miRNA expression pattern of tumor cells [85]. miRNAs belonging to the miR-17-92 cluster were found to be significantly up-regulated only in MM samples but not in MGUS or healthy PCs [16] and the expression of this cluster is regulated by c-Myc in MM [86]. In this sense, it has been described that c-Myc inhibits apoptosis of MM cells by activation of miR-17-92 cluster, which leads to the downregulation of the proapoptotic protein Bim [86]. Other targets of that miRNA cluster are PTEN and E2F1, which support its tumor-promoting functions [87-91]. Recently, the miR-17-92 cluster was targeted with gapmeR (a chimeric antisense oligonucleotide that contains a central block of deoxynucleotide monomers sufficiently long to induce RNase H cleavage) antisense oligonucleotides, MIR17PTi, to induce degradation of MIR17HG primary transcripts and consequently prevent biogenesis of these miRNAs. As a result, MIR17PTi induced cell growth impairment, apoptosis, senescence and sensitized MM cells resistant to dexamethasone, melphalan or bortezomib. Moreover, treatment with MIR17PTi induced death only in cells with active MYC, through the upregulation of proapoptotic protein BIM and tumor suppressors p21, TP53, E2F1 and PTEN [92]. This finding demonstrates the myc-dependent synthetic lethality of this compound in MM.

On the other hand, c-Myc takes part in a multi-component regulatory complex which trans-repress several miRNAs in MM, including $m i R-23 b, m i R-29 b$ or $m i R-29 a[75,93,94]$. The repression of $m i R-23 b$ and $m i R-29 b$ in MM leads to activation of Sp1, a transcription factor that regulates the expression of cell-cycle, differentiation, and apoptosis-related genes [93]. Many miRNAs and transcription factors form autoregulatory loops, in which they mutually regulate each other [95]. A miR-29b-Sp1 feedback regulatory loop was described in MM [96]. Moreover, the treatment of MM cells with bortezomib decreased the expression of Sp1 with the consequent increase of miR-29b level, indicating that this miRNA can be regulated not only by c-Myc but also by Sp1 [75]. 
TP53 is a tumor suppressor that interacts with numerous pathways and is commonly mutated in various cancers. However, in MM TP53 mutations are not so frequent and p53 seems rather to be inactivated by other multiple factors (reviewed in [97]). Recent studies have demonstrated that miRNAs interact with p53 and this network regulates the p53 level, and, in turn, p53 also regulates the transcription, expression and the maturation of a group of miRNAs $[28,98,99]$. In MM, an autoregulatory loop between the miR-194-2-192 cluster and p53 has been discovered, in which p53 acts as a transcriptional activator of pri-miR-194-2 by directly binding to its core promoter element, and those miRNAs directly target $3^{\prime} \mathrm{UTR}$ of TP53 [28]. Moreover, BMM induces expression of miR-125-5p in MM, leading to decrease of p53 expression and consequently, decrease of the p53-regulated miR-194-2-192 cluster [100].

The knowledge of transcriptional regulation of miRNAs expression will help us better understand not only the function of miRNAs but also the effect of deregulation of transcription factors in MM.

\section{Impaired miRNA Processing may Deregulate miRNA Expression}

The biologically active miRNAs are generated in a two-step sequential mechanism involving two RNase III nucleases, Drosha and Dicer. The downregulations of these key factors in the biogenesis of miRNA has been reported in many cancer types (reviewed in [101]). Processing of the hairpin precursor (pre-miRNA) through Dicer generates a miRNA duplex, consisting of a miRNA (5p strand) and miRNA* (3p strand). The miRNA machinery is orchestrated by two major multiprotein complexes, the Drosha complex in the nucleus, and the cytoplasmatic RNA-induced silencing complex (RISC), which contains the Argonaute (Ago) family proteins as a core component (Figure 3) (reviewed in $[12,14,102-107])$. One of these strands generated by Dicer, known as the guide arm, will be incorporated into the RISC complex while the other, known as the passenger strand, will be degraded. One of the two strands is preferentially selected as a guide, either $5 p$ or $3 p$. While either of the miRNAs strands can be used equally, the selection of the strand is highly regulated and depends on cell/tissue type [71,108]. The relationship between expression of sister miRNAs was compared in $\mathrm{MM}$ and other pathologies, such as acute lymphoblastic leukemia and prostate cancer, and the ratio between expression values of sister miRNAs was able to distinguish MM from other tissues [71]. The two mature miRNAs ( $3 p$ and $5 p$ ) have partially reversed complementary sequences and tend to have different targeting properties [109].

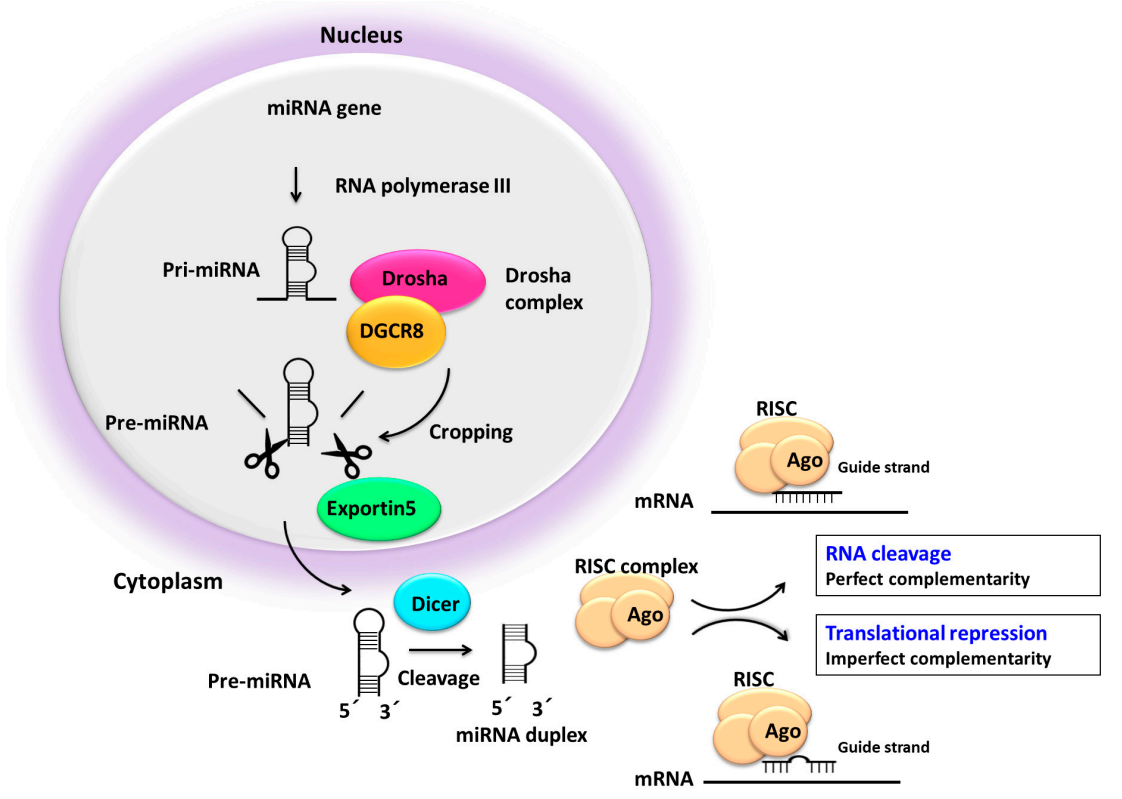

Figure 3. miRNA biogenesis pathway. RISC: RNA-induced silencing complex; Ago: Argonaute family proteins. 
The application of deep sequencing technologies to short RNAs and the analyses of pre-miRNA processing have led to the discovery of a distinct class of small RNAs known as moRNAs (miRNA-offset RNAs) derived from the sequence flaking $5^{\prime}$ - or $3^{\prime}$ arm pre-miRNA [110]. MoRNAs found in human tissues are generally included in the miRNA hairpin precursor [111]. Although the biogenesis and function of moRNAs remains unclear, it has been hypothesized that moRNA biogenesis might be associated with pre-miRNA processing $[112,113]$. Some data indicate that moRNAs may repress target transcripts as miRNAs do [114]. On the other hand, nuclear moRNA enrichment found in metazoan cells might indicate their role in regulating epigenomic modifications and transcription [115]. Likewise, the function of moRNAs in MM remains to be elucidated.

The ubiquitously expressed ubiquitin E3 ligase protein, cereblon, has been identified as a direct target of antimyeloma immunomodulatory drugs, like lenalidomide [116,117]. Remarkably, the Ago2 protein was found to be a substrate for the cereblon protein. Upon treatment of MM cells with lenalidomide, the level of Ago2 protein decreased with the consequent downregulation of global miRNA expression level. In line with this, the knocking down of AGO2 and Dicer significantly decreased growth and viability of myeloma cells [118]. Moreover, silencing of $A G O 2$ led to decrease of the total miRNA level $[118,119]$. Moreover, Ago2 is involved in promoting angiogenesis by miRNA-mediated regulation of pro- and anti-angiogenic signals $[120,121]$. Expression of AGO2 mRNA, however, did not significantly associate with global miRNA expression in primary MM cells [118]. Dicer mRNA level in NPC was very similar to MGUS, a pre-malignant condition, and significantly higher than in smoldering myeloma (SMM) and MM [122]. Moreover, higher expression of Dicer was associated with improved progression-free survival in symptomatic myeloma patients [122]. Dicer silencing led to cell cycle inhibition in MM cell lines [118], while higher Dicer expression was not associated with cell-cycle activation of proliferation in primary MM cells [122]. These results suggest that the effect of Dicer downregulation might be different in cell lines compared to the pathophysiological effect in primary MM. It is noteworthy that the miRNA expression level in MM is also affected by mutual crosstalk between myeloma cells and BMM, leading to the deregulation of certain miRNAs in MM [76].

Overall, these studies support that idea that the altered expression of proteins involved in the biogenesis of miRNAs may affect the MM pathogenesis.

\section{Impact of miRNA-mRNA Associations}

It is estimated that miRNAs repress the translation of approximately $30-50 \%$ of all the coding genes [123]. The effect of miRNAs usually induces a negative correlation between their expression levels and their target genes. However, this is not always the case and sometimes the regulatory effect is only observed at translation, with a low effect on the mRNA transcript levels [124,125]. miRNA-mediated gene regulation has a broad impact on gene expression since a single miRNA can control many transcripts and, in turn, a single transcript can be regulated by many miRNAs [126]. All these factors mean that the accurate identification of the targets regulated by miRNAs remains a challenge. Traditionally, miRNA-mRNA associations have been predicted using bioinformatic algorithms based on the sequence conservation between the miRNA and the target gene, such as miRanda [127], PicTar [128] or TargetScan [129]. More sophisticated approaches include other parameters such as the binding free energy and the secondary structure of the $3^{\prime} \mathrm{UTR}$ of the target gene. These improvements were implemented in tools such as PITA [130] or rna22 [131]. Nevertheless, even though these methods can identify the regulatory potential of miRNAs, it is noteworthy that they cannot reach the miRNA-targeted mRNA pairs with biological significance, as it depends on the association between the expression levels of both molecules and the biological context [132]. In recent years, the use of high-throughput techniques, such as microarrays, has enabled the detection of potential associations between miRNA and mRNA levels. However, these approaches alone are still limited at the time of revealing the mechanisms involved in the transcriptional cascade and how they are regulated. Many bioinformatic tools have been developed to integrate all these data through 
the generation of co-expression networks, using methods based on correlation [133] or Bayesian inference [134,135] or "mixed regulatory circuits reconstruction" [136]. These networks are built from expression data at both miRNA and mRNA level in order to identify critical genes in the network structure and to determine new regulatory relationships. Genes and miRNA are represented as the nodes of the network and the edge that connects two nodes represents the relationship between them. The aim of these methods is to detect the critical elements in the network, identifying the essential nodes and edges in the network structure. In summary, methods based on miRNA and mRNA expression integration have the major advantage of considering the biological background of the studied samples, however, all the strategies mentioned above require further validation. The in silico approach for validation is to use and compare different algorithms to predict the miRNA-mRNA interactions [137,138], which is widely recommended before the target validation experiments [138]. Several experimental strategies have been performed to determine the truthfulness and the biological significance of the miRNA-targeted mRNA interaction [139-141]. The most commonly used strategies are the validation of the expression of the miRNA and its targeted mRNA through qRT-PCR or Northern blot, and the demonstration of the miRNA interaction with a target site using the luciferase reporter assay [141]. However, although the use of these approaches is much extended in the literature, both have their pros and cons. The main disadvantage of co-expression assays is that they cannot differentiate direct and indirect miRNA targets [140], so it is not possible to know whether a miRNA directly interacts with an mRNA, or whether this effect is mediated by another target molecule. In the case of the luciferase reporter assay, the main drawbacks are that they depend on the cloning region and the variability of the protocol [140]. Because of this, it is necessary to combine different validation strategies to effectively determine the miRNA-mRNA interactions [140].

The expression of the miRNA and its targeted mRNA has also been actively studied in MM $[15,17,132,142,143]$. In silico analysis of the relationship between the miRNA and mRNA expression profiling in the context of the different MM cytogenetic subgroups has shown interactions involving genes related to biological pathways that could play a relevant role in the development of MM [15]. In the $\mathrm{t}(4 ; 14)$ subgroup, miR-135b and miR-146a targeted PELI2 and IRAK1 genes, which are involved in the IL1 signaling pathway. A batch of four genes (GPD2, GLCCI1, FNDC3B and ASH2L) previously reported in cancer development were found to be targeted by the $m i R-1$ in the $t(14 ; 16)$ subgroup. Concerning the 13q deletion, the potential regulation of the MAPK pathway by miRNAs was highlighted. A final comparison among all cytogenetic subgroups revealed that some miRNA-mRNA interactions involving the CCND2 gene were commonly dysregulated in the $t(4 ; 14), t(14 ; 16)$ and 13q deletion subgroups, suggesting the potential targeting of CCND2 by miRNAs in MM. Interactions were considered true positive when they were predicted by at least three out of the four algorithms used for the integrative analysis: TargetScan, miRDB, miRanda and Pictar. A similar study was performed through an integrative analysis with a correlation network of functional interactions [17]. This study identified more than 23,000 regulatory relationships involving 628 miRNAs and 6435 genes, which were considered real interactions if they were within the top 3\% of the anti-correlated miRNA-targeted mRNA pairs. The most consistent sub-network was the corresponding to the $t(4 ; 14)$, which grouped seven miRNAs and 289 targets. In this sub-network, three of the target genes (CBFA2T2, PP1R16B and GOSR2) were commonly regulated by five miRNAs.

\section{Single Nucleotide Polymorphisms and 3'UTR Polyadenylation Affect miRNA Binding Sites}

The function of miRNAs may also be affected by sequence variations in miRNA binding sites, such as mutations and single nucleotide polymorphisms (SNPs) in the $3^{\prime}$ UTR. These genetic variations inside $3^{\prime}$ UTRs may overlap with miRNA binding sites and impair the translation inhibition or degradation of the mRNAs, or create new miRNA binding sites [144]. Computational analysis has identified more than 400 SNPs located within predicted and experimentally verified miRNA-binding sites [25]. Moreover, in recent years several studies have shown associations between SNPs in miRNA-binding-sites (miRSNPs) and cancer (reviewed in [145]). The first evidence for miRSNPs 
associated with hematological malignancies arise from a study in $\mathrm{MM}$, in which the prognostic impact of six miRSNPs, located either in miRNAs target genes or in miRNA biogenesis pathway proteins, was evaluated. Only two miRSNPs, rs3660 in the KRT81 gene and rs11077 in the XPO5 gene, which were experimentally validated using renilla/luciferase reporter assays, were associated with better prognosis in MM after autologous stem cell transplantation [146] (Figure 4, left side).

On the other hand, another study based on computational prediction using genome-wide analysis and meta-analysis found five SNPs associated with MM risk [147] (Figure 4, right side).

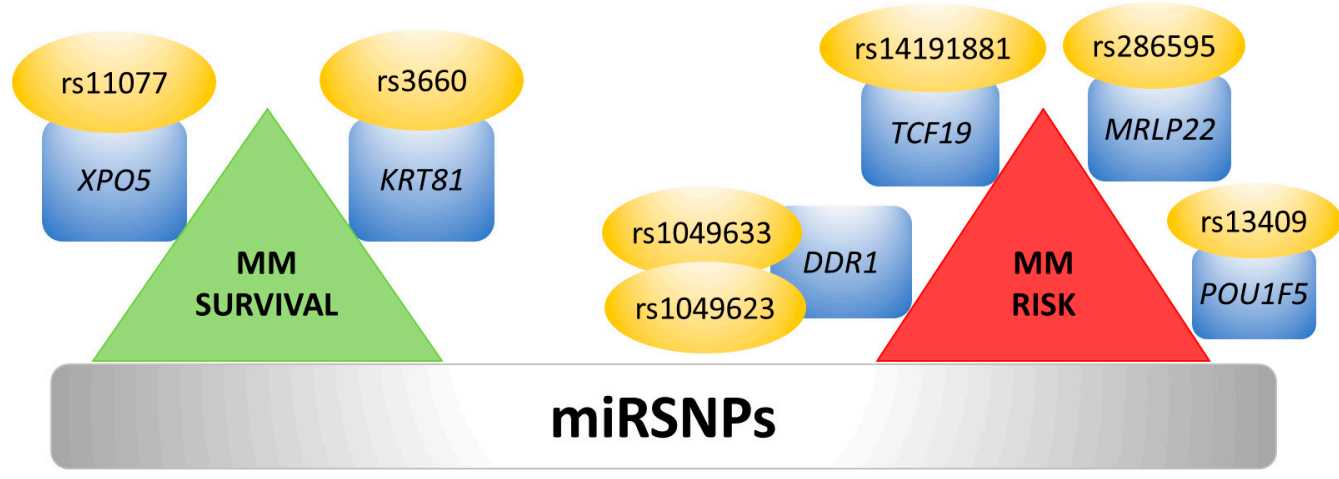

Figure 4. Relevant SNPs in miRNA-binding-sites (miRSNPs) studied in MM cells.

Cancer cells often express substantial amounts of mRNA isoforms with shorter $3^{\prime} \mathrm{UTR}$ regions that usually result from alternative cleavage and polyadenylation (APA) [148]. The loss of miRNA-mediated repression due to the alternative cleavage and APA enhances the generation of shorter mRNAs isoforms that exhibit higher stability and produce more proteins $[148,149]$. This mechanism seems to be involved in the overexpression of CCND2 in multiple myeloma. In fact, the shortening of CCND2 3'UTR by alternative polyadenylation with the consequent loss of miRNA binding sites was demonstrated both in myeloma cell lines and primary myeloma samples [150].

\section{Regulation of miRNA Expression by miRNA Sponges}

miRNA activity can be affected not only by the aforementioned factors, but also by regulatory RNA species, the so-called competing endogenous RNA (ceRNAs) or miRNA 'sponges'. Sponge RNAs contain binding sites for miRNAs, and hence compete with target mRNAs for miRNA binding (Figure 5). RNAs that may function as sponges include long noncoding RNAs (lncRNAs), RNAs encoded by pseudogenes and circular RNAs (reviewed in [151]). Furthermore, highly abundant mRNAs have also been described to serve as endogenous sponges, since they may sequester miRNAs and suppress their activity over other mRNA targets. In general, miRNAs are stable and destroy targeted mRNAs. However, research suggests that endogenous targets may also control miRNAs by target RNA-directed miRNA degradation (TDMD) [152]. Interestingly, it has been described that some miRNAs can induce the degradation of specific circular RNAs after binding, whereas others are resistant and therefore act as strong miRNA sponges [153]. The ability to act as a miRNA sponge is also increased by the presence of multiple tandem high-affinity binding sites to a microRNA. Thus, the circular RNA sponge for miR-7 (ciRS-7) contains $>60$ conserved miR-7 seed matches and, therefore, can bind densely to this miRNA [154]. 


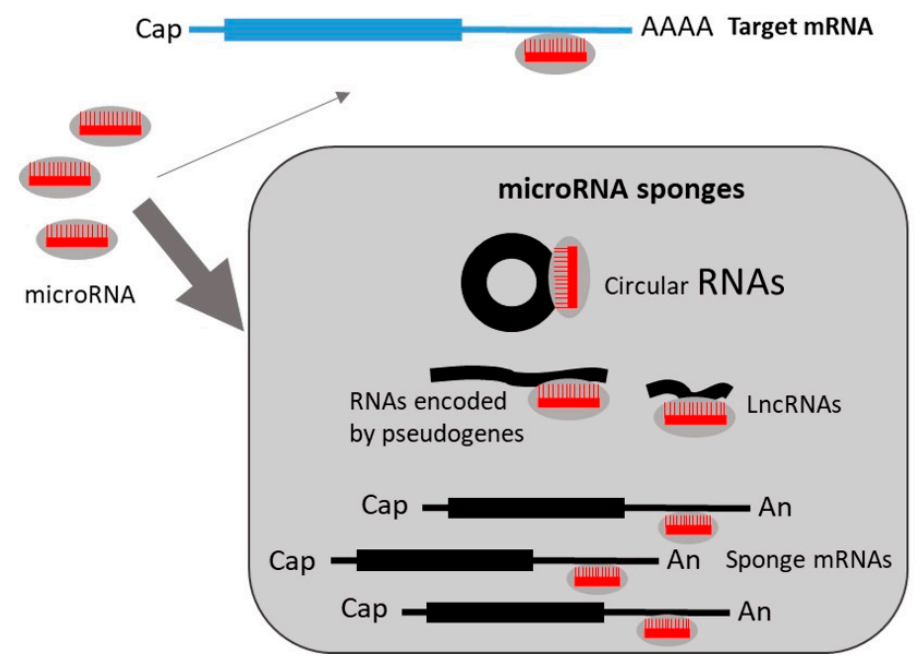

Figure 5. Regulation of miRNA activity on target mRNAs by miRNA sponges.

The influence of miRNA sponges in the regulation of cancer-associated genes is nicely illustrated by PTEN, one of the most frequently disrupted tumor suppressors in cancer [155]. Several protein-coding ceRNAs have been identified that share miRNA target sites with PTEN. Moreover, PTEN levels are also regulated by a PTEN pseudogene, PTENP1, which acts as a ceRNA by providing additional miRNA target sites [156]. Deregulation of these PTEN-ceRNAs seems to be responsible for PTEN under-expression in some tumors [157]. Other ceRNAs that influence cancer-related factors have been described [156], such as LncRNA CRNDE, which is overexpressed in colorectal cancer and promotes cell proliferation and metastasis $[158,159]$. Overexpression of CRNDE has also been found in MM and has been related to tumor progression and poor survival [160]. The authors reported that $C R N D E$ induced the proliferation and an antiapoptotic response in MM by sponging miR-451. The lncRNAs, CCAT1 and MALAT1, which are also overexpressed in MM [161-163], have been shown to promote MM cell growth by functioning as ceRNA for miR-181a-5p and miR-509-5p, respectively [161,164]. The lowered availability of these miRNAs increased the abundance of the tumor-promoting factors HOXA1 and FOXP1, respectively.

In analogy with naturally occurring miRNA suppression mechanisms, artificially custom-designed sponges can be exploited for inhibition of miRNA activity (Reviewed in [165]). In fact, knockdown of overexpressed oncogenic miRNAs with this technology can be a therapeutic strategy for cancer [166]. Thus, in MM it has been reported that inhibition of miR-19 and miR-155 activity with "traditional" or artificially-improved sponges increases SOCS1 levels, leading to enhanced activity of tumor suppressor p53 and inhibition of the transformed phenotype [167]. The deepest knowledge of miRNA sponges will pave the way to manipulate miRNA functions in MM and other cancer cells.

\section{Conclusions}

A full understanding of the role of miRNAs in MM pathogenesis requires not only exploration of the different effects of the deregulation of mature miRNAs, but also unveiling of the factors that regulate their expression and ultimately determine their function. These factors encompass the genomic modifications of DNA sequences encoding miRNAs, including DNA methylation, which is one of the most significant mechanisms that regulate miRNA expression in $\mathrm{MM}$, the transcriptional regulation of miRNAs and, finally, variations in the mRNA target sites. Moreover, other elements, such as competing endogenous RNA and alterations in the complex enzymatic machinery that generate the mature and active miRNAs, may affect their final expression.

The understanding of the complex mechanisms of regulation that determine the expression and functionality of the mature miRNAs in MM may open new avenues for investigation, particularly in the field of therapeutic interventions. 
Author Contributions: I.M.-K. organized the complete review, contributed to the writing of the main topics of the manuscript and wrote the "Copy number abnormalities affect expression of miRNAs" and the "Transcriptional regulation of miRNAs expression" sections; P.K. wrote the "MicroRNA expression and epigenetics." section; L.A.C. wrote the "Impact of miRNA-mRNA associations" section; D.Q. wrote the "Impaired miRNA processing may deregulate miRNA expression" section; A.B.H. the "Regulation of miRNA expression by miRNA sponges" section; E.A.R. wrote the "Single nucleotide polymorphisms and $3^{\prime}$ UTR polyadenylation affect miRNA binding sites" section; and N.C.G. corrected and reviewed the whole manuscript.

Funding: This research received no external funding. Elizabeta A. Rojas was supported by: “Fondo Social Europeo (FEDER)" and “Consejería de Educación de Castilla y León".

Conflicts of Interest: The authors declare no conflict of interest.

\section{References}

1. Kumar, S.K.; Therneau, T.M.; Gertz, M.A.; Lacy, M.Q.; Dispenzieri, A.; Rajkumar, S.V.; Fonseca, R.; Witzig, T.E.; Lust, J.A.; Larson, D.R.; et al. Clinical course of patients with relapsed multiple myeloma. Mayo Clin. Proc. 2004, 79, 867-874. [CrossRef]

2. Avet-Loiseau, H.; Li, C.; Magrangeas, F.; Gouraud, W.; Charbonnel, C.; Harousseau, J.-L.; Attal, M.; Marit, G.; Mathiot, C.; Facon, T.; et al. Prognostic significance of copy-number alterations in multiple myeloma. J. Clin. Oncol. Off. J. Am. Soc. Clin. Oncol. 2009, 27, 4585-4590. [CrossRef] [PubMed]

3. Fonseca, R.; Harrington, D.; Oken, M.M.; Dewald, G.W.; Bailey, R.J.; Van Wier, S.A.; Henderson, K.J.; Blood, E.A.; Rajkumar, S.V.; Kay, N.E.; et al. Biological and prognostic significance of interphase fluorescence in situ hybridization detection of chromosome 13 abnormalities (delta13) in multiple myeloma: An eastern cooperative oncology group study. Cancer Res. 2002, 62, 715-720.

4. Gutiérrez, N.C.; Castellanos, M.V.; Martín, M.L.; Mateos, M.V.; Hernández, J.M.; Fernández, M.; Carrera, D.; Rosiñol, L.; Ribera, J.M.; Ojanguren, J.M.; et al. Prognostic and biological implications of genetic abnormalities in multiple myeloma undergoing autologous stem cell transplantation: $t(4 ; 14)$ is the most relevant adverse prognostic factor, whereas RB deletion as a unique abnormality is not associated with adverse prognosis. Leukemia 2007, 21, 143-150. [PubMed]

5. Morgan, G.J.; Walker, B.A.; Davies, F.E. The genetic architecture of multiple myeloma. Nat. Rev. Cancer 2012, 12, 335-348. [CrossRef] [PubMed]

6. Baskerville, S.; Bartel, D.P. Microarray profiling of microRNAs reveals frequent coexpression with neighboring miRNAs and host genes. RNA 2005, 11, 241-247. [CrossRef] [PubMed]

7. Altuvia, Y.; Landgraf, P.; Lithwick, G.; Elefant, N.; Pfeffer, S.; Aravin, A.; Brownstein, M.J.; Tuschl, T.; Margalit, H. Clustering and conservation patterns of human microRNAs. Nucleic Acids Res. 2005, 33, 2697-2706. [CrossRef]

8. Kozomara, A.; Griffiths-Jones, S. miRBase: Annotating high confidence microRNAs using deep sequencing data. Nucleic Acids Res. 2014, 42, D68-D73. [CrossRef]

9. Ling, H.; Fabbri, M.; Calin, G.A. MicroRNAs and other non-coding RNAs as targets for anticancer drug development. Nat. Rev. Drug Discov. 2013, 12, 847-865. [CrossRef]

10. Ambros, V. MicroRNAs and developmental timing. Curr. Opin. Genet. Dev. 2011, 21, 511-517. [CrossRef]

11. Ambros, V.; Chen, X. The regulation of genes and genomes by small RNAs. Dev. Camb. Engl. 2007, 134, 1635-1641. [CrossRef] [PubMed]

12. Ambros, V. The functions of animal microRNAs. Nature 2004, 431, 350-355. [CrossRef] [PubMed]

13. Bartel, D.P. Metazoan MicroRNAs. Cell 2018, 173, 20-51. [CrossRef]

14. Bartel, D.P. MicroRNAs: Genomics, biogenesis, mechanism, and function. Cell 2004, 116, 281-297. [CrossRef]

15. Gutiérrez, N.C.; Sarasquete, M.E.; Misiewicz-Krzeminska, I.; Delgado, M.; De Las Rivas, J.; Ticona, F.V.; Fermiñán, E.; Martín-Jiménez, P.; Chillón, C.; Risueño, A.; et al. Deregulation of microRNA expression in the different genetic subtypes of multiple myeloma and correlation with gene expression profiling. Leukemia 2010, 24, 629-637. [CrossRef]

16. Pichiorri, F.; Suh, S.-S.; Ladetto, M.; Kuehl, M.; Palumbo, T.; Drandi, D.; Taccioli, C.; Zanesi, N.; Alder, H.; Hagan, J.P.; et al. MicroRNAs regulate critical genes associated with multiple myeloma pathogenesis. Proc. Natl. Acad. Sci. USA 2008, 105, 12885-12890. [CrossRef] [PubMed] 
17. Lionetti, M.; Biasiolo, M.; Agnelli, L.; Todoerti, K.; Mosca, L.; Fabris, S.; Sales, G.; Deliliers, G.L.; Bicciato, S.; Lombardi, L.; et al. Identification of microRNA expression patterns and definition of a microRNA/mRNA regulatory network in distinct molecular groups of multiple myeloma. Blood 2009, 114, e20-e26. [CrossRef]

18. Misiewicz-Krzeminska, I.; Sarasquete, M.E.; Quwaider, D.; Krzeminski, P.; Ticona, F.V.; Paíno, T.; Delgado, M.; Aires, A.; Ocio, E.M.; García-Sanz, R.; et al. Restoration of microRNA-214 expression reduces growth of myeloma cells through positive regulation of P53 and inhibition of DNA replication. Haematologica 2013, 98, 640-648. [CrossRef]

19. Quwaider, D.; Corchete, L.A.; Misiewicz-Krzeminska, I.; Sarasquete, M.E.; Pérez, J.J.; Krzeminski, P.; Puig, N.; Mateos, M.V.; García-Sanz, R.; Herrero, A.B.; et al. DEPTOR maintains plasma cell differentiation and favorably affects prognosis in multiple myeloma. J. Hematol. Oncol. 2017, 10, 92. [CrossRef]

20. Li, Y.; Zhang, B.; Li, W.; Wang, L.; Yan, Z.; Li, H.; Yao, Y.; Yao, R.; Xu, K.; Li, Z. MiR-15a/16 regulates the growth of myeloma cells, angiogenesis and antitumor immunity by inhibiting Bcl-2, VEGF-A and IL-17 expression in multiple myeloma. Leuk. Res. 2016, 49, 73-79. [CrossRef]

21. Amodio, N.; Stamato, M.A.; Gullà, A.M.; Morelli, E.; Romeo, E.; Raimondi, L.; Pitari, M.R.; Ferrandino, I.; Misso, G.; Caraglia, M.; et al. Therapeutic Targeting of miR-29b/HDAC4 Epigenetic Loop in Multiple Myeloma. Mol. Cancer Ther. 2016, 15, 1364-1375. [CrossRef] [PubMed]

22. Lu, Y.; Wu, D.; Wang, J.; Li, Y.; Chai, X.; Kang, Q. miR-320a regulates cell proliferation and apoptosis in multiple myeloma by targeting pre-B-cell leukemia transcription factor 3. Biochem. Biophys. Res. Commun. 2016, 473, 1315-1320. [CrossRef] [PubMed]

23. Yu, T.; Zhang, X.; Zhang, L.; Wang, Y.; Pan, H.; Xu, Z.; Pang, X. MicroRNA-497 suppresses cell proliferation and induces apoptosis through targeting PBX3 in human multiple myeloma. Am. J. Cancer Res. 2016, 6, 2880-2889. [PubMed]

24. Yang, Y.; Li, F.; Saha, M.N.; Abdi, J.; Qiu, L.; Chang, H. miR-137 and miR-197 Induce Apoptosis and Suppress Tumorigenicity by Targeting MCL-1 in Multiple Myeloma. Clin. Cancer Res. Off. J. Am. Assoc. Cancer Res. 2015, 21, 2399-2411. [CrossRef]

25. Saunders, M.A.; Liang, H.; Li, W.-H. Human polymorphism at microRNAs and microRNA target sites. Proc. Natl. Acad. Sci. USA 2007, 104, 3300-3305. [CrossRef] [PubMed]

26. Chen, K.; Rajewsky, N. Natural selection on human microRNA binding sites inferred from SNP data. Nat. Genet. 2006, 38, 1452-1456. [CrossRef] [PubMed]

27. Hanamura, I.; Stewart, J.P.; Huang, Y.; Zhan, F.; Santra, M.; Sawyer, J.R.; Hollmig, K.; Zangarri, M.; Pineda-Roman, M.; van Rhee, F.; et al. Frequent gain of chromosome band 1q21 in plasma-cell dyscrasias detected by fluorescence in situ hybridization: Incidence increases from MGUS to relapsed myeloma and is related to prognosis and disease progression following tandem stem-cell transplantation. Blood 2006, 108, 1724-1732. [CrossRef]

28. Pichiorri, F.; Suh, S.-S.; Rocci, A.; De Luca, L.; Taccioli, C.; Santhanam, R.; Zhou, W.; Benson, D.M.; Hofmainster, C.; Alder, H.; et al. Downregulation of p53-inducible microRNAs 192, 194, and 215 impairs the p53/MDM2 autoregulatory loop in multiple myeloma development. Cancer Cell 2010, 18, 367-381. [CrossRef]

29. Zhang, Y.; Geng, L.; Talmon, G.; Wang, J. MicroRNA-520g confers drug resistance by regulating p21 expression in colorectal cancer. J. Biol. Chem. 2015, 290, 6215-6225. [CrossRef]

30. Liu, R.; Liu, F.; Li, L.; Sun, M.; Chen, K. MiR-498 regulated FOXO3 expression and inhibited the proliferation of human ovarian cancer cells. Biomed. Pharmacother. 2015, 72, 52-57. [CrossRef]

31. Roccaro, A.M.; Sacco, A.; Thompson, B.; Leleu, X.; Azab, A.K.; Azab, F.; Runnels, J.; Jia, X.; Ngo, H.T.; Melhem, M.R.; et al. MicroRNAs 15a and 16 regulate tumor proliferation in multiple myeloma. Blood 2009, 113, 6669-6680. [CrossRef] [PubMed]

32. Gao, X.; Zhang, R.; Qu, X.; Zhao, M.; Zhang, S.; Wu, H.; Jianyong, L.; Chen, L. MiR-15a, miR-16-1 and miR-17-92 cluster expression are linked to poor prognosis in multiple myeloma. Leuk. Res. 2012, 36, 1505-1509. [CrossRef] [PubMed]

33. Lionetti, M.; Agnelli, L.; Mosca, L.; Fabris, S.; Andronache, A.; Todoerti, K.; Ronchetti, D.; Deliliers, G.L.; Neri, A. Integrative high-resolution microarray analysis of human myeloma cell lines reveals deregulated miRNA expression associated with allelic imbalances and gene expression profiles. Genes. Chromosomes Cancer 2009, 48, 521-531. [CrossRef] [PubMed] 
34. Zhang, J.; Yang, Y.; Yang, T.; Liu, Y.; Li, A.; Fu, S.; Wu, M.; Pan, Z.; Zhou, W. microRNA-22, downregulated in hepatocellular carcinoma and correlated with prognosis, suppresses cell proliferation and tumourigenicity. Br. J. Cancer 2010, 103, 1215-1220. [CrossRef]

35. Xia, S.-S.; Zhang, G.-J.; Liu, Z.-L.; Tian, H.-P.; He, Y.; Meng, C.-Y.; Li, L.-F.; Wang, Z.-W.; Zhou, T. MicroRNA-22 suppresses the growth, migration and invasion of colorectal cancer cells through a Sp1 negative feedback loop. Oncotarget 2017, 8, 36266-36278. [CrossRef] [PubMed]

36. Guo, M.-M.; Hu, L.-H.; Wang, Y.-Q.; Chen, P.; Huang, J.-G.; Lu, N.; He, J.-H.; Liao, C.-G. miR-22 is down-regulated in gastric cancer, and its overexpression inhibits cell migration and invasion via targeting transcription factor Sp1. Med. Oncol. 2013, 30, 542. [CrossRef] [PubMed]

37. Ling, B.; Wang, G.-X.; Long, G.; Qiu, J.-H.; Hu, Z.-L. Tumor suppressor miR-22 suppresses lung cancer cell progression through post-transcriptional regulation of ErbB3. J. Cancer Res. Clin. Oncol. 2012, 138, 1355-1361. [CrossRef]

38. Lee, H.; Han, S.; Kwon, C.S.; Lee, D. Biogenesis and regulation of the let-7 miRNAs and their functional implications. Protein Cell 2016, 7, 100-113. [CrossRef]

39. Johnson, S.M.; Grosshans, H.; Shingara, J.; Byrom, M.; Jarvis, R.; Cheng, A.; Labourier, E.; Reinert, K.L.; Brown, D.; Slack, F.J. RAS is regulated by the let-7 microRNA family. Cell 2005, 120, 635-647. [CrossRef]

40. Sampson, V.B.; Rong, N.H.; Han, J.; Yang, Q.; Aris, V.; Soteropoulos, P.; Petrelli, N.J.; Dunn, S.P.; Krueger, L.J. MicroRNA let-7a down-regulates MYC and reverts MYC-induced growth in Burkitt lymphoma cells. Cancer Res. 2007, 67, 9762-9770. [CrossRef]

41. Takamizawa, J.; Konishi, H.; Yanagisawa, K.; Tomida, S.; Osada, H.; Endoh, H.; Harano, T.; Yatabe, Y.; Nagino, M.; Nimura, Y.; et al. Reduced expression of the let-7 microRNAs in human lung cancers in association with shortened postoperative survival. Cancer Res. 2004, 64, 3753-3756. [CrossRef] [PubMed]

42. Shell, S.; Park, S.-M.; Radjabi, A.R.; Schickel, R.; Kistner, E.O.; Jewell, D.A.; Feig, C.; Lengyel, E.; Peter, M.E. Let-7 expression defines two differentiation stages of cancer. Proc. Natl. Acad. Sci. USA 2007, 104, 11400-11405. [CrossRef]

43. Bird, A. DNA methylation patterns and epigenetic memory. Genes Dev. 2002, 16, 6-21. [CrossRef]

44. Koch, A.; Joosten, S.C.; Feng, Z.; de Ruijter, T.C.; Draht, M.X.; Melotte, V.; Smits, K.M.; Veeck, J.; Herman, J.G.; Van Neste, L.; et al. Analysis of DNA methylation in cancer: Location revisited. Nat. Rev. Clin. Oncol. 2018, 15, 459-466. [CrossRef]

45. Walker, B.A.; Wardell, C.P.; Chiecchio, L.; Smith, E.M.; Boyd, K.D.; Neri, A.; Davies, F.E.; Ross, F.M.; Morgan, G.J. Aberrant global methylation patterns affect the molecular pathogenesis and prognosis of multiple myeloma. Blood 2011, 117, 553-562. [CrossRef] [PubMed]

46. Heuck, C.J.; Mehta, J.; Bhagat, T.; Gundabolu, K.; Yu, Y.; Khan, S.; Chrysofakis, G.; Schinke, C.; Tariman, J.; Vickrey, E.; et al. Myeloma is characterized by stage-specific alterations in DNA methylation that occur early during myelomagenesis. J. Immunol. 2013, 190, 2966-2975. [CrossRef]

47. Chim, C.S.; Wong, K.Y.; Qi, Y.; Loong, F.; Lam, W.L.; Wong, L.G.; Jin, D.Y.; Costello, J.F.; Liang, R. Epigenetic inactivation of the miR-34a in hematological malignancies. Carcinogenesis 2010, 31, 745-750. [CrossRef]

48. Zhang, W.; Wang, Y.E.; Zhang, Y.; Leleu, X.; Reagan, M.; Zhang, Y.; Mishima, Y.; Glavey, S.; Manier, S.; Sacco, A.; et al. Global epigenetic regulation of microRNAs in multiple myeloma. PLoS ONE 2014, 9, e110973. [CrossRef]

49. Wong, K.-Y.; Liang, R.; So, C.-C.; Jin, D.-Y.; Costello, J.F.; Chim, C.-S. Epigenetic silencing of MIR203 in multiple myeloma. Br. J. Haematol. 2011, 154, 569-578. [CrossRef] [PubMed]

50. Wong, K.Y.; Yim, R.L.H.; So, C.C.; Jin, D.-Y.; Liang, R.; Chim, C.S. Epigenetic inactivation of the MIR34B/C in multiple myeloma. Blood 2011, 118, 5901-5904. [CrossRef]

51. Wong, K.-Y.; Yim, R.L.-H.; Kwong, Y.-L.; Leung, C.-Y.; Hui, P.-K.; Cheung, F.; Liang, R.; Jin, D.-Y.; Chim, C.-S. Epigenetic inactivation of the MIR129-2 in hematological malignancies. J. Hematol. Oncol. 2013, 6, 16. [CrossRef] [PubMed]

52. Li, Z.; Wong, K.Y.; Chan, G.C.-F.; Chng, W.-J.; Chim, C.S. Epigenetic silencing of EVL/miR-342 in multiple myeloma. Transl. Res. J. Lab. Clin. Med. 2018, 192, 46-53. [CrossRef] [PubMed]

53. Tatekawa, S.; Chinen, Y.; Ri, M.; Narita, T.; Shimura, Y.; Matsumura-Kimoto, Y.; Tsukamoto, T.; Kobayashi, T.; Kawata, E.; Uoshima, N.; et al. Epigenetic repression of miR-375 is the dominant mechanism for constitutive activation of the PDPK1/RPS6KA3 signalling axis in multiple myeloma. Br. J. Haematol. 2017, 178, 534-546. [CrossRef] [PubMed] 
54. Moutinho, C.; Esteller, M. MicroRNAs and Epigenetics. Adv. Cancer Res. 2017, 135, 189-220. [PubMed]

55. Zhao, S.; Wang, Y.; Liang, Y.; Zhao, M.; Long, H.; Ding, S.; Yin, H.; Lu, Q. MicroRNA-126 regulates DNA methylation in CD4+ T cells and contributes to systemic lupus erythematosus by targeting DNA methyltransferase 1. Arthritis Rheum. 2011, 63, 1376-1386. [CrossRef]

56. Takata, A.; Otsuka, M.; Yoshikawa, T.; Kishikawa, T.; Hikiba, Y.; Obi, S.; Goto, T.; Kang, Y.J.; Maeda, S.; Yoshida, H.; et al. MicroRNA-140 acts as a liver tumor suppressor by controlling NF- $\kappa$ B activity by directly targeting DNA methyltransferase 1 (Dnmt1) expression. Hepatology 2013, 57, 162-170. [CrossRef]

57. Yuan, L.; Chan, G.C.F.; Fung, K.L.; Chim, C.S. RANKL expression in myeloma cells is regulated by a network involving RANKL promoter methylation, DNMT1, microRNA and TNF $\alpha$ in the microenvironment. Biochim. Biophys. Acta 2014, 1843, 1834-1838. [CrossRef]

58. Amodio, N.; D’Aquila, P.; Passarino, G.; Tassone, P.; Bellizzi, D. Epigenetic modifications in multiple myeloma: Recent advances on the role of DNA and histone methylation. Expert Opin. Ther. Targets 2017, 21, 91-101. [CrossRef]

59. Amodio, N.; Leotta, M.; Bellizzi, D.; Di Martino, M.T.; D'Aquila, P.; Lionetti, M.; Fabiani, F.; Leone, E.; Gullà, A.M.; Passarino, G.; et al. DNA-demethylating and anti-tumor activity of synthetic miR-29b mimics in multiple myeloma. Oncotarget 2012, 3, 1246-1258. [CrossRef]

60. Stamato, M.A.; Juli, G.; Romeo, E.; Ronchetti, D.; Arbitrio, M.; Caracciolo, D.; Neri, A.; Tagliaferri, P.; Tassone, P.; Amodio, N. Inhibition of EZH2 triggers the tumor suppressive miR-29b network in multiple myeloma. Oncotarget 2017, 8, 106527-106537. [CrossRef]

61. Zhang, Y.-K.; Wang, H.; Leng, Y.; Li, Z.-L.; Yang, Y.-F.; Xiao, F.-J.; Li, Q.-F.; Chen, X.-Q.; Wang, L.-S. Overexpression of microRNA-29b induces apoptosis of multiple myeloma cells through down regulating Mcl-1. Biochem. Biophys. Res. Commun. 2011, 414, 233-239. [CrossRef]

62. Jagannathan, S.; Vad, N.; Vallabhapurapu, S.; Vallabhapurapu, S.; Anderson, K.C.; Driscoll, J.J. MiR-29b replacement inhibits proteasomes and disrupts aggresome+autophagosome formation to enhance the antimyeloma benefit of bortezomib. Leukemia 2015, 29, 727-738. [CrossRef]

63. Zhang, Q.; Wang, L.Q.; Wong, K.Y.; Li, Z.Y.; Chim, C.S. Infrequent DNA methylation of miR-9-1 and miR-9-3 in multiple myeloma. J. Clin. Pathol. 2015, 68, 557-561. [CrossRef] [PubMed]

64. Canella, A.; Cordero Nieves, H.; Sborov, D.W.; Cascione, L.; Radomska, H.S.; Smith, E.; Stiff, A.; Consiglio, J.; Caserta, E.; Rizzotto, L.; et al. HDAC inhibitor AR-42 decreases CD44 expression and sensitizes myeloma cells to lenalidomide. Oncotarget 2015, 6, 31134-31150. [CrossRef]

65. Li, Z.; Wong, K.Y.; Chan, G.C.-F.; Chim, C.S. Epigenetic silencing of LPP/miR-28 in multiple myeloma. J. Clin. Pathol. 2018, 71, 253-258. [CrossRef] [PubMed]

66. Wu, S.; He, X.; Li, M.; Shi, F.; Wu, D.; Pan, M.; Guo, M.; Zhang, R.; Luo, S.; Gu, N.; et al. MiRNA-34a overexpression inhibits multiple myeloma cancer stem cell growth in mice by suppressing TGIF2. Am. J. Transl. Res. 2016, 8, 5433-5443. [PubMed]

67. Wong, K.Y.; So, C.C.; Loong, F.; Chung, L.P.; Lam, W.W.L.; Liang, R.; Li, G.K.H.; Jin, D.-Y.; Chim, C.S. Epigenetic inactivation of the miR-124-1 in haematological malignancies. PLoS ONE 2011, 6, e19027. [CrossRef] [PubMed]

68. Krzeminski, P.; Sarasquete, M.E.; Misiewicz-Krzeminska, I.; Corral, R.; Corchete, L.A.; Martín, A.A.; García-Sanz, R.; San Miguel, J.F.; Gutiérrez, N.C. Insights into epigenetic regulation of microRNA-155 expression in multiple myeloma. Biochim. Biophys. Acta 2015, 1849, 353-366. [CrossRef] [PubMed]

69. Bi, C.; Chung, T.-H.; Huang, G.; Zhou, J.; Yan, J.; Ahmann, G.J.; Fonseca, R.; Chng, W.J. Genome-wide pharmacologic unmasking identifies tumor suppressive microRNAs in multiple myeloma. Oncotarget 2015, 6, 26508-26518. [CrossRef] [PubMed]

70. Schanen, B.C.; Li, X. Transcriptional regulation of mammalian miRNA genes. Genomics 2011, 97, 1-6. [CrossRef]

71. Biasiolo, M.; Sales, G.; Lionetti, M.; Agnelli, L.; Todoerti, K.; Bisognin, A.; Coppe, A.; Romualdi, C.; Neri, A.; Bortoluzzi, S. Impact of host genes and strand selection on miRNA and miRNA* expression. PLoS ONE 2011, 6, e23854. [CrossRef]

72. Ronchetti, D.; Lionetti, M.; Mosca, L.; Agnelli, L.; Andronache, A.; Fabris, S.; Deliliers, G.L.; Neri, A. An integrative genomic approach reveals coordinated expression of intronic miR-335, miR-342, and miR-561 with deregulated host genes in multiple myeloma. BMC Med. Genom. 2008, 1, 37. [CrossRef] [PubMed] 
73. Löffler, D.; Brocke-Heidrich, K.; Pfeifer, G.; Stocsits, C.; Hackermüller, J.; Kretzschmar, A.K.; Burger, R.; Gramatzki, M.; Blumert, C.; Bauer, K.; et al. Interleukin-6 dependent survival of multiple myeloma cells involves the Stat3-mediated induction of microRNA-21 through a highly conserved enhancer. Blood 2007, 110, 1330-1333. [CrossRef]

74. Song Gao, J.; Zhang, Y.; Li, M.; Tucker, L.D.; Machan, J.T.; Quesenberry, P.; Rigoutsos, I.; Ramratnam, B. Atypical transcription of microRNA gene fragments. Nucleic Acids Res. 2010, 38, 2775-2787. [CrossRef] [PubMed]

75. Amodio, N.; Di Martino, M.T.; Foresta, U.; Leone, E.; Lionetti, M.; Leotta, M.; Gullà, A.M.; Pitari, M.R.; Conforti, F.; Rossi, M.; et al. miR-29b sensitizes multiple myeloma cells to bortezomib-induced apoptosis through the activation of a feedback loop with the transcription factor Sp1. Cell Death Dis. 2012, 3, e436. [CrossRef] [PubMed]

76. Raimondi, L.; De Luca, A.; Morelli, E.; Giavaresi, G.; Tagliaferri, P.; Tassone, P.; Amodio, N. MicroRNAs: Novel Crossroads between Myeloma Cells and the Bone Marrow Microenvironment. BioMed Res. Int. 2016, 2016, 6504593. [CrossRef]

77. Bhattacharya, S.; Ray, R.M.; Johnson, L.R. STAT3-mediated transcription of Bcl-2, Mcl-1 and c-IAP2 prevents apoptosis in polyamine-depleted cells. Biochem. J. 2005, 392, 335-344. [CrossRef]

78. Sepúlveda, P.; Encabo, A.; Carbonell-Uberos, F.; Miñana, M.D. BCL-2 expression is mainly regulated by JAK/STAT3 pathway in human CD34+ hematopoietic cells. Cell Death Differ. 2007, 14, 378-380. [CrossRef] [PubMed]

79. Ma, J.; Gong, W.; Liu, S.; Li, Q.; Guo, M.; Wang, J.; Wang, S.; Chen, N.; Wang, Y.; Liu, Q.; et al. Ibrutinib targets microRNA-21 in multiple myeloma cells by inhibiting NF-кB and STAT3. Tumour Biol. 2018, 40, 1010428317731369. [CrossRef]

80. Raimondi, L.; Amodio, N.; Di Martino, M.T.; Altomare, E.; Leotta, M.; Caracciolo, D.; Gullà, A.; Neri, A.; Taverna, S.; D'Aquila, P.; et al. Targeting of multiple myeloma-related angiogenesis by miR-199a-5p mimics: In vitro and in vivo anti-tumor activity. Oncotarget 2014, 5, 3039-3054. [CrossRef]

81. Borsi, E.; Perrone, G.; Terragna, C.; Martello, M.; Dico, A.F.; Solaini, G.; Baracca, A.; Sgarbi, G.; Pasquinelli, G.; Valente, S.; et al. Hypoxia inducible factor-1 alpha as a therapeutic target in multiple myeloma. Oncotarget 2014, 5, 1779-1792. [CrossRef] [PubMed]

82. Holien, T.; Våtsveen, T.K.; Hella, H.; Waage, A.; Sundan, A. Addiction to c-MYC in multiple myeloma. Blood 2012, 120, 2450-2453. [CrossRef]

83. Vigorito, E.; Perks, K.L.; Abreu-Goodger, C.; Bunting, S.; Xiang, Z.; Kohlhaas, S.; Das, P.P.; Miska, E.A.; Rodriguez, A.; Bradley, A.; et al. microRNA-155 regulates the generation of immunoglobulin class-switched plasma cells. Immunity 2007, 27, 847-859. [CrossRef]

84. Danger, R.; Braza, F.; Giral, M.; Soulillou, J.-P.; Brouard, S. MicroRNAs, Major Players in B Cells Homeostasis and Function. Front. Immunol. 2014, 5, 98. [CrossRef] [PubMed]

85. Chang, T.-C.; Yu, D.; Lee, Y.-S.; Wentzel, E.A.; Arking, D.E.; West, K.M.; Dang, C.V.; Thomas-Tikhonenko, A.; Mendell, J.T. Widespread microRNA repression by Myc contributes to tumorigenesis. Nat. Genet. 2008, 40, 43-50. [CrossRef] [PubMed]

86. Chen, L.; Li, C.; Zhang, R.; Gao, X.; Qu, X.; Zhao, M.; Qiao, C.; Xu, J.; Li, J. miR-17-92 cluster microRNAs confers tumorigenicity in multiple myeloma. Cancer Lett. 2011, 309, 62-70. [CrossRef] [PubMed]

87. Novotny, G.W.; Sonne, S.B.; Nielsen, J.E.; Jonstrup, S.P.; Hansen, M.A.; Skakkebaek, N.E.; Rajpert-De Meyts, E.; Kjems, J.; Leffers, H. Translational repression of E2F1 mRNA in carcinoma in situ and normal testis correlates with expression of the miR-17-92 cluster. Cell Death Differ. 2007, 14, 879-882. [CrossRef] [PubMed]

88. O'Donnell, K.A.; Wentzel, E.A.; Zeller, K.I.; Dang, C.V.; Mendell, J.T. c-Myc-regulated microRNAs modulate E2F1 expression. Nature 2005, 435, 839-843. [CrossRef]

89. Concepcion, C.P.; Bonetti, C.; Ventura, A. The microRNA-17-92 family of microRNA clusters in development and disease. Cancer J. Sudbury Mass 2012, 18, 262-267. [CrossRef]

90. Mogilyansky, E.; Rigoutsos, I. The miR-17/92 cluster: A comprehensive update on its genomics, genetics, functions and increasingly important and numerous roles in health and disease. Cell Death Differ. 2013, 20, 1603-1614. [CrossRef] 
91. Ventura, A.; Young, A.G.; Winslow, M.M.; Lintault, L.; Meissner, A.; Erkeland, S.J.; Newman, J.; Bronson, R.T.; Crowley, D.; Stone, J.R.; et al. Targeted deletion reveals essential and overlapping functions of the miR-17 through 92 family of miRNA clusters. Cell 2008, 132, 875-886. [CrossRef] [PubMed]

92. Morelli, E.; Biamonte, L.; Federico, C.; Amodio, N.; Di Martino, M.T.; Gallo Cantafio, M.E.; Manzoni, M.; Scionti, F.; Samur, M.K.; Gullà, A.; et al. Therapeutic vulnerability of multiple myeloma to MIR17PTi, a first-in-class inhibitor of pri-miR-17-92. Blood 2018, 132, 1050-1063. [CrossRef] [PubMed]

93. Fulciniti, M.; Amodio, N.; Bandi, R.L.; Cagnetta, A.; Samur, M.K.; Acharya, C.; Prabhala, R.; D'Aquila, P.; Bellizzi, D.; Passarino, G.; et al. miR-23b/SP1/c-myc forms a feed-forward loop supporting multiple myeloma cell growth. Blood Cancer J. 2016, 6, e380. [CrossRef] [PubMed]

94. Saha, M.N.; Abdi, J.; Yang, Y.; Chang, H. MiRNA-29a as a tumor suppressor mediates PRIMA-1Met-induced anti-myeloma activity by targeting c-Myc. Oncotarget 2016, 7, 7149-7160. [CrossRef] [PubMed]

95. Tsang, J.; Zhu, J.; van Oudenaarden, A. MicroRNA-mediated feedback and feedforward loops are recurrent network motifs in mammals. Mol. Cell 2007, 26, 753-767. [CrossRef] [PubMed]

96. Mott, J.L.; Kurita, S.; Cazanave, S.C.; Bronk, S.F.; Werneburg, N.W.; Fernandez-Zapico, M.E. Transcriptional suppression of mir-29b-1/mir-29a promoter by c-Myc, hedgehog, and NF-kappaB. J. Cell. Biochem. 2010, 110, 1155-1164. [CrossRef]

97. Herrero, A.B.; Rojas, E.A.; Misiewicz-Krzeminska, I.; Krzeminski, P.; Gutiérrez, N.C. Molecular Mechanisms of p53 Deregulation in Cancer: An Overview in Multiple Myeloma. Int. J. Mol. Sci. 2016, 17, 2003. [CrossRef]

98. Feng, Z.; Zhang, C.; Wu, R.; Hu, W. Tumor suppressor p53 meets microRNAs. J. Mol. Cell Biol. 2011, 3, 44-50. [CrossRef]

99. Liu, J.; Zhang, C.; Zhao, Y.; Feng, Z. MicroRNA Control of p53. J. Cell. Biochem. 2017, 118, 7-14. [CrossRef]

100. Leotta, M.; Biamonte, L.; Raimondi, L.; Ronchetti, D.; Di Martino, M.T.; Botta, C.; Leone, E.; Pitari, M.R.; Neri, A.; Giordano, A.; et al. A p53-dependent tumor suppressor network is induced by selective miR-125a-5p inhibition in multiple myeloma cells. J. Cell. Physiol. 2014, 229, 2106-2116. [CrossRef]

101. Rupaimoole, R.; Calin, G.A.; Lopez-Berestein, G.; Sood, A.K. miRNA Deregulation in Cancer Cells and the Tumor Microenvironment. Cancer Discov. 2016, 6, 235-246. [CrossRef]

102. Borchert, G.M.; Lanier, W.; Davidson, B.L. RNA polymerase III transcribes human microRNAs. Nat. Struct. Mol. Biol. 2006, 13, 1097-1101. [CrossRef] [PubMed]

103. Lee, Y.; Ahn, C.; Han, J.; Choi, H.; Kim, J.; Yim, J.; Lee, J.; Provost, P.; Rådmark, O.; Kim, S.; et al. The nuclear RNase III Drosha initiates microRNA processing. Nature 2003, 425, 415-419. [CrossRef] [PubMed]

104. Han, J.; Lee, Y.; Yeom, K.-H.; Nam, J.-W.; Heo, I.; Rhee, J.-K.; Sohn, S.Y.; Cho, Y.; Zhang, B.-T.; Kim, V.N. Molecular basis for the recognition of primary microRNAs by the Drosha-DGCR8 complex. Cell 2006, 125, 887-901. [CrossRef]

105. Zeng, Y.; Cullen, B.R. Structural requirements for pre-microRNA binding and nuclear export by Exportin 5 . Nucleic Acids Res. 2004, 32, 4776-4785. [CrossRef]

106. Winter, J.; Jung, S.; Keller, S.; Gregory, R.I.; Diederichs, S. Many roads to maturity: microRNA biogenesis pathways and their regulation. Nat. Cell Biol. 2009, 11, 228-234. [CrossRef] [PubMed]

107. Ha, M.; Kim, V.N. Regulation of microRNA biogenesis. Nat. Rev. Mol. Cell Biol. 2014, 15, 509-524. [CrossRef]

108. Kuchenbauer, F.; Mah, S.M.; Heuser, M.; McPherson, A.; Rüschmann, J.; Rouhi, A.; Berg, T.; Bullinger, L.; Argiropoulos, B.; Morin, R.D.; et al. Comprehensive analysis of mammalian miRNA* species and their role in myeloid cells. Blood 2011, 118, 3350-3358. [CrossRef]

109. Marco, A.; Macpherson, J.I.; Ronshaugen, M.; Griffiths-Jones, S. MicroRNAs from the same precursor have different targeting properties. Silence 2012, 3, 8. [CrossRef]

110. Shi, Q.; He, Q.; Wei, J. MicroRNA-342 prohibits proliferation and invasion of melanoma cells by directly targeting Zinc-finger E-box binding homeobox 1. Oncol. Res. 2018, 26, 1447-1455. [CrossRef]

111. Langenberger, D.; Bermudez-Santana, C.; Hertel, J.; Hoffmann, S.; Khaitovich, P.; Stadler, P.F. Evidence for human microRNA-offset RNAs in small RNA sequencing data. Bioinform. Oxf. Engl. 2009, 25, 2298-2301. [CrossRef]

112. Bortoluzzi, S.; Biasiolo, M.; Bisognin, A. MicroRNA-offset RNAs (moRNAs): By-product spectators or functional players? Trends Mol. Med. 2011, 17, 473-474. [CrossRef]

113. Nepal, C.; Coolen, M.; Hadzhiev, Y.; Cussigh, D.; Mydel, P.; Steen, V.M.; Carninci, P.; Andersen, J.B.; Bally-Cuif, L.; Müller, F.; et al. Transcriptional, post-transcriptional and chromatin-associated regulation of pri-miRNAs, pre-miRNAs and moRNAs. Nucleic Acids Res. 2016, 44, 3070-3081. [CrossRef] [PubMed] 
114. Umbach, J.L.; Strelow, L.I.; Wong, S.W.; Cullen, B.R. Analysis of rhesus rhadinovirus microRNAs expressed in virus-induced tumors from infected rhesus macaques. Virology 2010, 405, 592-599. [CrossRef] [PubMed]

115. Taft, R.J.; Simons, C.; Nahkuri, S.; Oey, H.; Korbie, D.J.; Mercer, T.R.; Holst, J.; Ritchie, W.; Wong, J.J.-L.; Rasko, J.E.J.; et al. Nuclear-localized tiny RNAs are associated with transcription initiation and splice sites in metazoans. Nat. Struct. Mol. Biol. 2010, 17, 1030-1034. [CrossRef]

116. Lu, G.; Middleton, R.E.; Sun, H.; Naniong, M.; Ott, C.J.; Mitsiades, C.S.; Wong, K.-K.; Bradner, J.E.; Kaelin, W.G. The myeloma drug lenalidomide promotes the cereblon-dependent destruction of Ikaros proteins. Science 2014, 343, 305-309. [CrossRef] [PubMed]

117. Krönke, J.; Udeshi, N.D.; Narla, A.; Grauman, P.; Hurst, S.N.; McConkey, M.; Svinkina, T.; Heckl, D.; Comer, E.; Li, X.; et al. Lenalidomide causes selective degradation of IKZF1 and IKZF3 in multiple myeloma cells. Science 2014, 343, 301-305. [CrossRef]

118. Zhou, Y.; Chen, L.; Barlogie, B.; Stephens, O.; Wu, X.; Williams, D.R.; Cartron, M.-A.; van Rhee, F.; Nair, B.; Waheed, S.; et al. High-risk myeloma is associated with global elevation of miRNAs and overexpression of EIF2C2/AGO2. Proc. Natl. Acad. Sci. USA 2010, 107, 7904-7909. [CrossRef] [PubMed]

119. Xu, Q.; Hou, Y.; Langlais, P.; Erickson, P.; Zhu, J.; Shi, C.-X.; Luo, M.; Zhu, Y.; Xu, Y.; Mandarino, L.J.; et al. Expression of the cereblon binding protein argonaute 2 plays an important role for multiple myeloma cell growth and survival. BMC Cancer 2016, 16, 297. [CrossRef]

120. Asai, T.; Suzuki, Y.; Matsushita, S.; Yonezawa, S.; Yokota, J.; Katanasaka, Y.; Ishida, T.; Dewa, T.; Kiwada, H.; Nango, M.; et al. Disappearance of the angiogenic potential of endothelial cells caused by Argonaute2 knockdown. Biochem. Biophys. Res. Commun. 2008, 368, 243-248. [CrossRef] [PubMed]

121. Wu, S.; Yu, W.; Qu, X.; Wang, R.; Xu, J.; Zhang, Q.; Xu, J.; Li, J.; Chen, L. Argonaute 2 promotes myeloma angiogenesis via microRNA dysregulation. J. Hematol. Oncol. 2014, 7, 40. [CrossRef] [PubMed]

122. Sarasquete, M.E.; Gutiérrez, N.C.; Misiewicz-Krzeminska, I.; Paiva, B.; Chillón, M.C.; Alcoceba, M.; García-Sanz, R.; Hernández, J.M.; González, M.; San-Miguel, J.F. Upregulation of Dicer is more frequent in monoclonal gammopathies of undetermined significance than in multiple myeloma patients and is associated with longer survival in symptomatic myeloma patients. Haematologica 2011, 96, 468-471. [CrossRef]

123. Tardito, D.; Mallei, A.; Popoli, M. Lost in translation. New unexplored avenues for neuropsychopharmacology: Epigenetics and microRNAs. Expert Opin. Investig. Drugs 2013, 22, 217-233. [CrossRef]

124. Croce, C.M.; Calin, G.A. miRNAs, cancer, and stem cell division. Cell 2005, 122, 6-7. [CrossRef] [PubMed]

125. Esquela-Kerscher, A.; Slack, F.J. Oncomirs-MicroRNAs with a role in cancer. Nat. Rev. Cancer 2006, 6, 259-269. [CrossRef] [PubMed]

126. Jin, H.; Tuo, W.; Lian, H.; Liu, Q.; Zhu, X.-Q.; Gao, H. Strategies to identify microRNA targets: New advances. New Biotechnol. 2010, 27, 734-738. [CrossRef]

127. John, B.; Enright, A.J.; Aravin, A.; Tuschl, T.; Sander, C.; Marks, D.S. Human MicroRNA targets. PLoS Biol. 2004, 2, e363. [CrossRef]

128. Krek, A.; Grün, D.; Poy, M.N.; Wolf, R.; Rosenberg, L.; Epstein, E.J.; MacMenamin, P.; da Piedade, I.; Gunsalus, K.C.; Stoffel, M.; et al. Combinatorial microRNA target predictions. Nat. Genet. 2005, 37, 495-500. [CrossRef]

129. Lewis, B.P.; Burge, C.B.; Bartel, D.P. Conserved seed pairing, often flanked by adenosines, indicates that thousands of human genes are microRNA targets. Cell 2005, 120, 15-20. [CrossRef]

130. Kertesz, M.; Iovino, N.; Unnerstall, U.; Gaul, U.; Segal, E. The role of site accessibility in microRNA target recognition. Nat. Genet. 2007, 39, 1278-1284. [CrossRef]

131. Miranda, K.C.; Huynh, T.; Tay, Y.; Ang, Y.-S.; Tam, W.-L.; Thomson, A.M.; Lim, B.; Rigoutsos, I. A pattern-based method for the identification of MicroRNA binding sites and their corresponding heteroduplexes. Cell 2006, 126, 1203-1217. [CrossRef] [PubMed]

132. Jayaswal, V.; Lutherborrow, M.; Ma, D.D.F.; Yang, Y.H. Identification of microRNA-mRNA modules using microarray data. BMC Genom. 2011, 12, 138. [CrossRef] [PubMed]

133. Langfelder, P.; Horvath, S. WGCNA: An R package for weighted correlation network analysis. BMC Bioinform. 2008, 9, 559. [CrossRef] [PubMed]

134. Bonneau, R.; Reiss, D.J.; Shannon, P.; Facciotti, M.; Hood, L.; Baliga, N.S.; Thorsson, V. The Inferelator: An algorithm for learning parsimonious regulatory networks from systems-biology data sets de novo. Genome Biol. 2006, 7, R36. [CrossRef] 
135. Farah, M.J.; Wallace, M.A. Semantically-bounded anomia: Implications for the neural implementation of naming. Neuropsychologia 1992, 30, 609-621. [CrossRef]

136. Bisognin, A.; Sales, G.; Coppe, A.; Bortoluzzi, S.; Romualdi, C. MAGIA ${ }^{2}$ : From miRNA and genes expression data integrative analysis to microRNA-transcription factor mixed regulatory circuits (2012 update). Nucleic Acids Res. 2012, 40, W13-W21. [CrossRef] [PubMed]

137. Conesa, A.; Madrigal, P.; Tarazona, S.; Gomez-Cabrero, D.; Cervera, A.; McPherson, A.; Szcześniak, M.W.; Gaffney, D.J.; Elo, L.L.; Zhang, X.; et al. A survey of best practices for RNA-seq data analysis. Genome Biol. 2016, 17, 13. [CrossRef]

138. Oliveira, A.C.; Bovolenta, L.A.; Nachtigall, P.G.; Herkenhoff, M.E.; Lemke, N.; Pinhal, D. Combining Results from Distinct MicroRNA Target Prediction Tools Enhances the Performance of Analyses. Front. Genet. 2017, 8, 59. [CrossRef]

139. Elton, T.S.; Yalowich, J.C. Experimental procedures to identify and validate specific mRNA targets of miRNAs. EXCLI J. 2015, 14, 758-790.

140. Thomson, D.W.; Bracken, C.P.; Goodall, G.J. Experimental strategies for microRNA target identification. Nucleic Acids Res. 2011, 39, 6845-6853. [CrossRef]

141. Kuhn, D.E.; Martin, M.M.; Feldman, D.S.; Terry, A.V.; Nuovo, G.J.; Elton, T.S. Experimental validation of miRNA targets. Methods San Diego Calif. 2008, 44, 47-54. [CrossRef]

142. Biasiolo, M.; Forcato, M.; Possamai, L.; Ferrari, F.; Agnelli, L.; Lionetti, M.; Todoerti, K.; Neri, A.; Marchiori, M.; Bortoluzzi, S.; et al. Critical analysis of transcriptional and post-transcriptional regulatory networks in multiple myeloma. Pac. Symp. Biocomput. Pac. Symp. Biocomput. 2010, 397-408.

143. Calura, E.; Bisognin, A.; Manzoni, M.; Todoerti, K.; Taiana, E.; Sales, G.; Morgan, G.J.; Tonon, G.; Amodio, N.; Tassone, P.; et al. Disentangling the microRNA regulatory milieu in multiple myeloma: Integrative genomics analysis outlines mixed miRNA-TF circuits and pathway-derived networks modulated in $\mathrm{t}(4 ; 14)$ patients. Oncotarget 2016, 7, 2367-2378. [CrossRef] [PubMed]

144. Cipolla, G.A.; Park, J.K.; de Oliveira, L.A.; Lobo-Alves, S.C.; de Almeida, R.C.; Farias, T.D.J.; de Lemos, D.S.; Malheiros, D.; Lavker, R.M.; Petzl-Erler, M.L. A 3'UTR polymorphism marks differential KLRG1 mRNA levels through disruption of a miR-584-5p binding site and associates with pemphigus foliaceus susceptibility. Biochim. Biophys. Acta 2016, 1859, 1306-1313. [CrossRef]

145. Salzman, D.W.; Weidhaas, J.B. SNPing cancer in the bud: microRNA and microRNA-target site polymorphisms as diagnostic and prognostic biomarkers in cancer. Pharmacol. Ther. 2013, 137, 55-63. [CrossRef] [PubMed]

146. de Larrea, C.F.; Navarro, A.; Tejero, R.; Tovar, N.; Díaz, T.; Cibeira, M.T.; Rosiñol, L.; Ferrer, G.; Rovira, M.; Rozman, M.; et al. Impact of MiRSNPs on survival and progression in patients with multiple myeloma undergoing autologous stem cell transplantation. Clin. Cancer Res. 2012, 18, 3697-3704. [CrossRef]

147. Macauda, A.; Calvetti, D.; Maccari, G.; Hemminki, K.; Försti, A.; Goldschmidt, H.; Weinhold, N.; Houlston, R.; Andersen, V.; Vogel, U.; et al. Identification of miRSNPs associated with the risk of multiple myeloma. Int. J. Cancer 2017, 140, 526-534. [CrossRef] [PubMed]

148. Mayr, C.; Bartel, D.P. Widespread shortening of 3'UTRs by alternative cleavage and polyadenylation activates oncogenes in cancer cells. Cell 2009, 138, 673-684. [CrossRef]

149. Wu, X.; Bartel, D.P. Widespread Influence of 3 '-End Structures on Mammalian mRNA Processing and Stability. Cell 2017, 169, 905-917.e11. [CrossRef] [PubMed]

150. Misiewicz-Krzeminska, I.; Sarasquete, M.E.; Vicente-Dueñas, C.; Krzeminski, P.; Wiktorska, K.; Corchete, L.A.; Quwaider, D.; Rojas, E.A.; Corral, R.; Martín, A.A.; et al. Post-transcriptional Modifications Contribute to the Upregulation of Cyclin D2 in Multiple Myeloma. Clin. Cancer Res. 2016, 22, 207-217. [CrossRef]

151. Bak, R.O.; Mikkelsen, J.G. miRNA sponges: Soaking up miRNAs for regulation of gene expression. Wiley Interdiscip. Rev. RNA 2014, 5, 317-333. [CrossRef] [PubMed]

152. Ghini, F.; Rubolino, C.; Climent, M.; Simeone, I.; Marzi, M.J.; Nicassio, F. Endogenous transcripts control miRNA levels and activity in mammalian cells by target-directed miRNA degradation. Nat. Commun. 2018, 9, 3119. [CrossRef]

153. Bonizzato, A.; Gaffo, E.; Te Kronnie, G.; Bortoluzzi, S. CircRNAs in hematopoiesis and hematological malignancies. Blood Cancer J. 2016, 6, e483. [CrossRef]

154. Panda, A.C. Circular RNAs Act as miRNA Sponges. Adv. Exp. Med. Biol. 2018, 1087, 67-79. [PubMed] 
155. Lee, Y.-R.; Chen, M.; Pandolfi, P.P. The functions and regulation of the PTEN tumour suppressor: New modes and prospects. Nat. Rev. Mol. Cell Biol. 2018, 19, 547-562. [CrossRef] [PubMed]

156. Poliseno, L.; Salmena, L.; Zhang, J.; Carver, B.; Haveman, W.J.; Pandolfi, P.P. A coding-independent function of gene and pseudogene mRNAs regulates tumour biology. Nature 2010, 465, 1033-1038. [CrossRef] [PubMed]

157. Tay, Y.; Kats, L.; Salmena, L.; Weiss, D.; Tan, S.M.; Ala, U.; Karreth, F.; Poliseno, L.; Provero, P.; Di Cunto, F.; et al. Coding-independent regulation of the tumor suppressor PTEN by competing endogenous mRNAs. Cell 2011, 147, 344-357. [CrossRef]

158. Gao, H.; Song, X.; Kang, T.; Yan, B.; Feng, L.; Gao, L.; Ai, L.; Liu, X.; Yu, J.; Li, H. Long noncoding RNA CRNDE functions as a competing endogenous RNA to promote metastasis and oxaliplatin resistance by sponging miR-136 in colorectal cancer. OncoTargets Ther. 2017, 10, 205-216. [CrossRef]

159. Han, P.; Li, J.-W.; Zhang, B.-M.; Lv, J.-C.; Li, Y.-M.; Gu, X.-Y.; Yu, Z.-W.; Jia, Y.-H.; Bai, X.-F.; $\mathrm{Li}, \mathrm{L} . ;$ et al. The lncRNA CRNDE promotes colorectal cancer cell proliferation and chemoresistance via miR-181a-5p-mediated regulation of Wnt/ $\beta$-catenin signaling. Mol. Cancer 2017, 16, 9. [CrossRef] [PubMed]

160. Meng, Y.-B.; He, X.; Huang, Y.-F.; Wu, Q.-N.; Zhou, Y.-C.; Hao, D.-J. Long Noncoding RNA CRNDE Promotes Multiple Myeloma Cell Growth by Suppressing miR-451. Oncol. Res. 2017, 25, 1207-1214. [CrossRef]

161. Chen, L.; Hu, N.; Wang, C.; Zhao, H.; Gu, Y. Long non-coding RNA CCAT1 promotes multiple myeloma progression by acting as a molecular sponge of miR-181a-5p to modulate HOXA1 expression. Cell Cycle Georget. Tex 2018, 17, 319-329. [CrossRef] [PubMed]

162. Amodio, N.; Stamato, M.A.; Juli, G.; Morelli, E.; Fulciniti, M.; Manzoni, M.; Taiana, E.; Agnelli, L.; Cantafio, M.E.G.; Romeo, E.; et al. Drugging the lncRNA MALAT1 via LNA gapmeR ASO inhibits gene expression of proteasome subunits and triggers anti-multiple myeloma activity. Leukemia 2018, 32, 1948-1957. [CrossRef] [PubMed]

163. Hu, Y.; Lin, J.; Fang, H.; Fang, J.; Li, C.; Chen, W.; Liu, S.; Ondrejka, S.; Gong, Z.; Reu, F.; et al. Targeting the MALAT1/PARP1/LIG3 complex induces DNA damage and apoptosis in multiple myeloma. Leukemia 2018, 32, 2250-2262. [CrossRef] [PubMed]

164. Gu, Y.; Xiao, X.; Yang, S. LncRNA MALAT1 acts as an oncogene in multiple myeloma through sponging miR-509-5p to modulate FOXP1 expression. Oncotarget 2017, 8, 101984-101993. [CrossRef]

165. Ebert, M.S.; Sharp, P.A. MicroRNA sponges: Progress and possibilities. RNA 2010, 16, 2043-2050. [CrossRef] [PubMed]

166. Tay, F.C.; Lim, J.K.; Zhu, H.; Hin, L.C.; Wang, S. Using artificial microRNA sponges to achieve microRNA loss-of-function in cancer cells. Adv. Drug Deliv. Rev. 2015, 81, 117-127. [CrossRef] [PubMed]

167. Mignacca, L.; Saint-Germain, E.; Benoit, A.; Bourdeau, V.; Moro, A.; Ferbeyre, G. Sponges against miR-19 and miR-155 reactivate the p53-Socs1 axis in hematopoietic cancers. Cytokine 2016, 82, 80-86. [CrossRef] 